\title{
Morphological Changes of the Lower Ping and Chao Phraya Rivers, North and Central Thailand: Flood and Coastal Equilibrium Analyses
}

https://doi.org/10.1515/geo-2019-0013

Received Aug 27, 2018; accepted Jan 29, 2019

Abstract: The Chao Phraya River flows in the largest river basin of Thailand and represents one of the important agricultural and industrial areas in Southeast Asia. The Ping River is one major upstream branch flowing down slope southwardly, joining the Chao Phraya River in the low-lying central plain and ending its course at the Gulf of Thailand. Surprisingly, the overflow occurs frequently and rapidly at the Lower Ping River where channel slope is high, and in particular area, sand-choked is extensively observed, even in normal rainfall condition. In contrary, at the downstream part, the erosion of river bank and shoreline around the mouth of Chao Phraya River has been spatially increasing in place where there should be a massive sediment supply to form a delta. Here we use Landsat imageries taken in 1987, 1997, 2007 and 2017 to analyze geomorphological changes of rivers. Results show that both rivers have undergone the rapid decreasing of water storage capacity and increasing of sand bar areas in river embayment. The total emerged sand bar area in the Lower Ping River increases from 1987 to 2017 up to $28.8 \mathrm{~km}^{2}$. The excessive trapped bed sediments deposition along the upper reaches is responsible for the shallower of river embankment leading to rapid overflow during flooding. At the Chao Phraya River mouth, a total of $18.8 \mathrm{~km}^{2}$ of the coastal area has been eroded from 1987 to 2017.This is caused by the reducing of sediment supply leading to nonequilibrium in the deltaic zone of the upper Gulf of Thailand. There are several possibility implications from this study involving construction of weir, in-channel sand mining, reservoir sedimentation and coastal erosion management.

Keywords: Lower Ping and Chao Phraya Rivers; Landsat imagery; river geomorphology; river regulation; sand bar

${ }^{\star}$ Corresponding Author: Montri Choowong: Morphology of Earth Surface and Advanced Geohazards in Southeast Asia Research Unit (MESA RU), Department of Geology, Faculty of Science, Chula-

\section{Introduction}

River morphological and sediment depositional changes can be caused by human activities, i.e., in-channel sand mining, dredging, deforestation, and construction of manmade structures such as weirs, barrages, and dams in a very short time, i.e. in a few decades [1-12]. Normally, sediment load is significantly trapped above a regulating structure and reduced downstream of it. This frequently results in river aggradation i.e. sand bar deposition, narrowing and shallowing of the river channel in the upstream and degradation, i.e. erosion of the river channel in the downstream from a dam [13-17]. In contrast, the effects of river adjustment caused by the natural factors require much longer time span to reveal. However, there are few exceptions that the natural factors such as river floods, landslide or earthquake can induce channel adjustments in a very short time [18-22]. Another factor that has been recognized in responsible for changes of rivers today is the climate change [23, 24]. However, it is quite difficult to distinguish climatic influences from anthropogenic causes [25]. Nonetheless, some studies have pointed out the effects of climate change on both hydraulic and sediment regimes in term of changes in water discharge, sediment supply rate, and stability within the fluvial systems [22, 26-32].

Change in river geomorphology and sediment depositional style can be investigated by both from field surveys as well as from remote sensing data [33-35]. However,

longkorn University, Phayathai Road, Pathumwan, Bangkok, 10330, Thailand; Email: montri.c@chula.ac.th

Nikhom Chaiwongsaen: Morphology of Earth Surface and Advanced Geohazards in Southeast Asia Research Unit (MESA RU), Department of Geology, Faculty of Science, Chulalongkorn University, Phayathai Road, Pathumwan, Bangkok, 10330, Thailand Parisa Nimnate: Morphology of Earth Surface and Advanced Geohazards in Southeast Asia Research Unit (MESA RU), Department of Geology, Faculty of Science, Chulalongkorn University, Phayathai Road, Pathumwan, Bangkok, 10330, Thailand; Division of Geoscience, Mahidol University, Kanchanaburi Campus, Kanchanaburi, 71150, Thailand

¿ Open Access. @ 2019 N. Chaiwongsaen et al., published by De Gruyter. (cc) BY BY This work is licensed under the Creative Commons Attribution 4.0 License 
in order to examine the cause and effect of the Ping and Chao Phraya Rivers problem thoroughly and effectively, the study area is bounded to cover a vast area from the upstream reaches of the river where the excessive sediment has been trapped continue to the downstream reaches where the severe erosion takes place. Hence, the most effective way to study these changes in river dynamic over a vast area and within a long period is using satellite imageries to track the river geomorphology and landform through time $[15,36-38]$. Therefore, the study area is set up to cover the Lower Ping River downstream of the Bhumibol Dam and continues to the end of the Chao Phraya River when entering the Gulf of Thailand for a stretch of around 1,000 km. In addition, the coastal area surrounding the Chao Phraya Delta was also examined (Figure 1A).

In the past decades, the increasing of sand bars in the Ping River has been recognized. Shallow sand-choked river causes flooding in rainy season repeatedly. Further downstream when the Ping River emerged with other tributaries and becomes the Chao Phraya River, the erosion of river banks and shoreline around its delta in the Gulf of Thailand has become an obvious issue instead $[39,40]$. In the past few years, Thailand has suffered from server flooding, especially the "2011 Great Flood" in the Chao Phraya River Basin and its distributary rivers including the Ping River [41-46].

The problem of excessive trapped bedload sediment in the Ping River has been ignored, for a long time. The high bedload sedimentation rate results in tremendous increasing of sand bars within the river. The sand bars have been increasing, especially between the succession of weir along the Ping River. The mean river water level above riverbed is very low due to this high sediment accumulation rate. This trapped bedload sediment with the addition of the reducing river's peak flow by the Bhumibol and the Lower Mae Ping Dams lower the water level below the propeller and sump levels of the irrigation pump stations situated along the river [47]. Recently, there are at least 10 existing pumping stations built by the Royal Irrigation Department (RID) which could not be fully operated to supply required water to the farmlands during drought seasons. Furthermore, the dredging projects have struggled to keep channels open to handle flood flows.

The morphodynamical changes of rivers are influenced by both anthropogenic activities and geologic conditions. The anthropogenic activities seem to have greater impact on accelerating the change in river dynamics and equilibrium in river reach scale. These factors include irrigation projects, deforestation for agriculture, and natural resources exploitations such as sand and gravel mining etc. [48-50]. On the other hand, the geologic conditions such as lithology and tectonic play an important role in controlling river equilibrium in the grander scale i.e. basinal scale and in a much longer time span. However, with exceptions some geologic (catastrophic) events as earthquake, river flooding, landslide, or debris flow can change the river equilibrium in a very short-term period [51, 52].

While trapped sediment in Ping River is commonly considered to be a significant problem, none of detailed study documents the related morphological changes of the rivers. Thus, the objective of this study is to detect and assess geomorphological changes of the Lower Ping and Chao Phraya Rivers during 1987 to 2017 inferred by Satellite-image analyses. The study emphasized on quantifying geomorphological changes in terms of the sand bar area, river width, and sinuosity using remote sensing data and GIS techniques. It is envisaged that the results from this study will shed light on how the influence of geological conditions and anthropogenic activities affect the geomorphology and sedimentation of the Ping and Chao Phraya Rivers, and will contribute to the substantial water resources and flooding management together with loss of equilibrium within the upstream and downstream parts of the Chao Phraya River basin.

\section{Material and methods}

In this study, Landsat imageries obtained after monsoon season during January to March of 1987, 1997, 2007 and 2017 with one decadal interval were selected to cover from when there is sufficient water in the main channel and when the land cloud cover is low as it is the dry season. The study area was covered by five Landsat scenes (path/row: 129 /50, 129/51, 130/49, 130/50, and 131/48). The Landsat archival data were available for the whole area. In total, 15 scenes of Landsat 5 TM (1987, 1997, and 2007) and 5 scenes of Landsat 8 OLI (2017) were used (Table 1). All satellite images were transformed to the Universal Transverse Mercator (UTM), World Geodetic System (WGS 84) projection. The geo-referenced images of each year have been mosaiced together. A uniform $30 \mathrm{~m}$ spatial resolution of all images was adequate to detect the dynamic changes of different periods of the Ping and Chao Phraya Rivers since the average river width of both rivers is approximately $265 \mathrm{~m}$. Initially, a supervised classification technique in ArcGIS was used to extract the water body and sand bar areas within the river. However, automated classification was found to be unusable because of mixed pixels between bank lines and sand bar boundaries. Hence, to maximize the data classification output, the river bank 

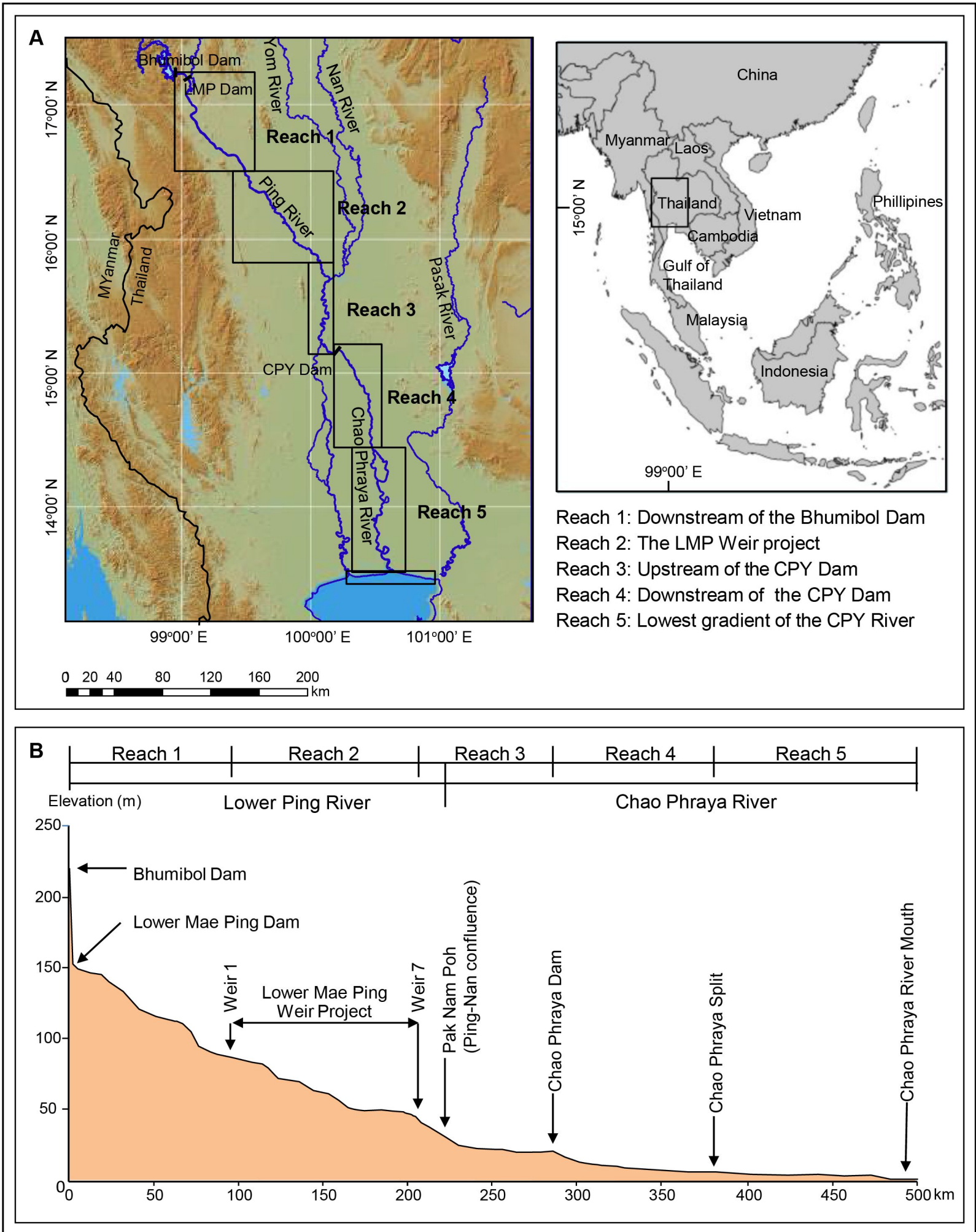

Figure 1: (A) Location map showing studied reaches (1-5) of the Lower Ping and Chao Phraya Rivers downstream from the Lower Mae Ping Dam to the Chao Phraya River mouth and the coastal area around its delta in the Gulf of Thailand. (B) Longitudinal profile of the Lower Ping River downstream of the Bhumibol Dam and the Chao Phraya River. 
Table 1: Specifications of Landsat imageries used in this study.

\begin{tabular}{|c|c|c|c|c|}
\hline Path/Row & Satellite & Satellite/Sensor & Acquisition Date & Spatial Resolution (m) \\
\hline \multirow{4}{*}{ 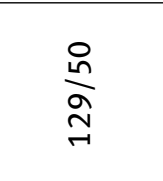 } & Landsat 5 & Thermal Infrared & $12 / 09 / 1987$ & 30 \\
\hline & Landsat 5 & Thermal Infrared & 04/24/1997 & 30 \\
\hline & Landsat 5 & Thermal Infrared & $02 / 15 / 2007$ & 30 \\
\hline & Landsat 8 & Combined OLI/TIRS & $03 / 14 / 2017$ & 30 \\
\hline \multirow{4}{*}{ 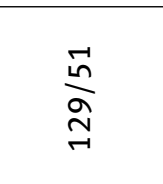 } & Landsat 5 & Thermal Infrared & $12 / 09 / 1987$ & 30 \\
\hline & Landsat 5 & Thermal Infrared & 04/24/1997 & 30 \\
\hline & Landsat 5 & Thermal Infrared & $02 / 15 / 2007$ & 30 \\
\hline & Landsat 8 & Combined OLI/TIRS & $03 / 14 / 2017$ & 30 \\
\hline \multirow{4}{*}{ 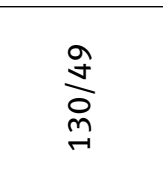 } & Landsat 5 & Thermal Infrared & $12 / 16 / 1987$ & 30 \\
\hline & Landsat 5 & Thermal Infrared & $02 / 10 / 1997$ & 30 \\
\hline & Landsat 5 & Thermal Infrared & $02 / 06 / 2007$ & 30 \\
\hline & Landsat 8 & Combined OLI/TIRS & $02 / 17 / 2017$ & 30 \\
\hline \multirow{4}{*}{ 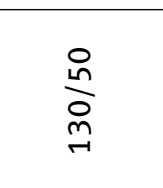 } & Landsat 5 & Thermal Infrared & $12 / 16 / 1987$ & 30 \\
\hline & Landsat 5 & Thermal Infrared & 04/15/1997 & 30 \\
\hline & Landsat 5 & Thermal Infrared & $02 / 06 / 2007$ & 30 \\
\hline & Landsat 8 & Combined OLI/TIRS & $02 / 17 / 2017$ & 30 \\
\hline \multirow{4}{*}{ 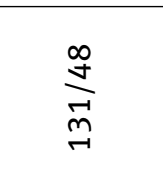 } & Landsat 5 & Thermal Infrared & $12 / 07 / 1987$ & 30 \\
\hline & Landsat 5 & Thermal Infrared & $01 / 16 / 1997$ & 30 \\
\hline & Landsat 5 & Thermal Infrared & $02 / 04 / 2007$ & 30 \\
\hline & Landsat 8 & Combined OLI/TIRS & $03 / 12 / 2017$ & 30 \\
\hline
\end{tabular}

lines and sand bars (subdivided into point/lateral bar and mid-channel bar) were digitized manually throughout the whole river reaches using ArcGIS v. 10.3. These data were analyzed and calculated the changes in geomorphology parameters over each period of rivers and also the change in shoreline along the Chao Phraya River delta.

In order to study the changes of the Lower Ping and Chao Phraya Rivers effectively, both the Lower Ping River downstream from the Bhumibol Dam and the Chao Phraya River were divided into five reaches according to the geological conditions, channel slope and intensity of river regulation. Changes of the river geomorphology along the Lower Ping River and the Chao Phraya River were estimated in terms of changes river width, sinuosity and sand bar area of the study reaches. Sand bars were categorized into two groups: mid-channel bars (islands) and point/lateral bars. Mid-channel bars are lands that, even in dry season, they are inundated or surrounded by water, while point/lateral bars, i.e. attached sand bars are accessible from the mainland without crossing a main channel. Besides changes of river width and sand bar areas, sinuosity is another important geomorphological parameter which identifies the dynamic nature of the Lower Ping and Chao Phraya Rivers. There are a limited number of previous researches or data that analyze the sinuosity of the Lower Ping and Chao Phraya Rivers over a long-time span and long range of rivers' courses. By using the four intervals of satellite images obtained in 1987, 1997, 2007 and 2017, the sinuosity indexes of the Lower Ping and Chao Phraya Rivers were computed.

\section{The study area}

The Chao Phraya River Basin coupled with the Ping River Basin is the largest river basin in Thailand covering almost one-third of the country. Both river basins are considered as one of the most regulated and disturbed areas in Thailand. The Ping River originates from the mountain range in the north and flows down through the intermontane basins and the Central Plain. The Lower Ping River conjunctions with the Wang River after leaving the mountain terrain, then with the Yom and Nan Rivers further downstream, and at this point it becomes the Chao Phraya River. Overall, the Ping and Chao Phraya Rivers combine parts of a change in channel slope that begin in high terrain of mountain range in the Northern Thailand and pass through the lowlands of the Central Plain, finally end up when the river mouth entering the Gulf of Thailand. In this study we selected only the lower part of the Ping River, called "the Lower Ping River" and the Chao Phraya River 
for the assessment (Figure 1A). The longitudinal profile of the Lower Ping and Chao Phraya Rivers downstream from the Bhumibol Dam was constructed using the elevation data from the Digital Elevation Model (DEM) (Figure 1B).

\subsection{The Lower Ping and Chao Phraya Rivers Catchments Characteristics}

The Lower Ping River Catchment is approximately 9,540 $\mathrm{km}^{2}$, and the river length is approximately $270 \mathrm{~km}$. At about $20 \mathrm{~km}$ South of Bhumibol Dam, the Lower Ping River is joined by the Wang river. Then it is jointed by the Nan River at the "Pak Nam Poh" (the beginning of the Chao Phraya River) in Nakhon Sawan province about $200 \mathrm{~km}$ north of Bangkok. It is located near the western margin of the Lower North region of Thailand. The Lower Ping covers substantial portions of Tak and Kamphaengphet provinces and includes only small portion of Nakhon Sawan province. In Tak province, the catchment includes substantial areas of hills and mountains at the western side. The Bhumibol Dam is located at the transition between the "Lower" and "Upper" parts of the Ping River. Beside the Bhumibol and the Lower Mae Ping (LMP) Dams installed at the head water of the Lower Ping River, within the lower half of the river course, the "Lower Mae Ping Weir Project", (a succession of seven weirs) had been installed just in the past decade. The slope of the Lower Ping River course above the weir project is around 0.00051 $\mathrm{m} / \mathrm{m}$, and between the weir project is around $0.00034 \mathrm{~m} / \mathrm{m}$. The lowland areas of Nakhon Sawan and Kamphaengphet provinces are contiguous with the lowlands of the Chao Phraya River Catchment, which is a part of the Central Plain.

The Chao Phraya River Catchment starts from "Pak Nam Poh" in Nakhon Sawan province. The Chao Phraya River Catchment area is approximately $17,270 \mathrm{~km}^{2}$, and the river length is approximately $712 \mathrm{~km}$. The river flows through the Central Plain passing through Bangkok toward the Gulf of Thailand. The Chao Phraya Dam (built in 1957) was constructed $96 \mathrm{~km}$ downstream from Nakhon Sawan province. This dam controls the discharge of the Chao Phraya River, and irrigation water is diverted to the left and right banks of the river. At about $55 \mathrm{~km}$ North of Bangkok, the Chao Phraya River is joined by the Pasak River. The embanked protecting is common throughout the river course. Numerous cannels interconnect the natural rivers, initially used mainly for transport in the past, and now for irrigation purpose. The Chao Phraya River is generally a gently sloped river. For example, the elevation is $15 \mathrm{~m}$ at the Chao Phraya Dam located $185 \mathrm{~km}$ from the river's mouth giving the slope of around 0.000065 $\mathrm{m} / \mathrm{m}$., and $7 \mathrm{~m}$ at the Chao Phraya River split in Ayutthaya province located $90 \mathrm{~km}$ from the river's mouth giving slope of around $0.000030 \mathrm{~m} / \mathrm{m}$.

\subsection{The Climatic setting}

According to the Thai Meteorological Department (TMD) [53], Thailand's climate endures three separate seasons: Rainy, Winter and Summer. The Rainy Season, also known as the Southwest Monsoon Season normally occurs between mid-May and mid-October. During this time, the Southwest Monsoon pattern prevails over central and northern sections of the country with the peak levels of precipitation normally received in August and September. The monsoon is supported by a stream of very warm, moist air approaching Thailand from the Indian Ocean. In addition to the southwest monsoon from the Indian Ocean, an active Inter-Tropical Convergence Zone (ITCZ) and the arrival of tropical cyclones also provide enhanced moisture. During the month of May, the ITCZ will first arrive in southern Thailand before shifting northward into central and northern Thailand during August. As the season begins to wind down, the ITCZ again sinks southward prior to the arrival of the Northeast Monsoon. Figure 2 shows the historical record of mean annual rainfall for the whole country. The mean annual rainfall in Thailand during 1951-2016 is 1,622 $\mathrm{mm}$. The eight years in which significant floods occurred $(1978,1980,1983,1995,1996,2002,2006$, and 2011) did exhibit above mean annual rainfall. However, not all years with heavy rainfall experienced severe floods, and not all years in which floods have occurred have been characterized by heavy rainfall. This indicates that there are various factors besides heavy rainfall involve in the likelihood of flooding in Thailand.

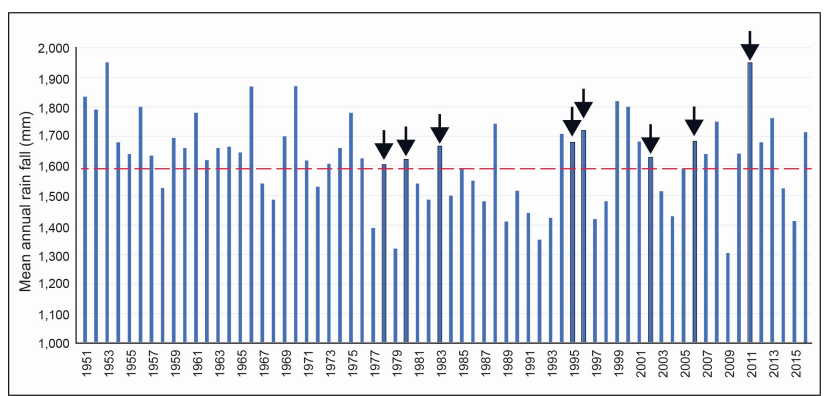

Figure 2: Mean annual rainfall for country from 1951 to 2016, the significant flood years $(1978,1980,1983,1995,1996,2002,2006$, and 2011) are highlighted with arrows; note that, in many cases, the large flood years are not associated with the highest rainfall. 
Climate of the Lower Ping and Chao Phraya river basins are also influence by monsoon. Occasionally, inflow runoff exceeds the upstream reservoir storage capacity and discharging to downstream that resulting in flood event and overflow in the end of August to December. Based on the historical hydrological data from the RID [54], the average discharge of the Chao Phraya River at Nakhon Sawan province is approximately $2,500 \mathrm{~m}^{3} / \mathrm{sec}$ while the discharge downstream of the Chao Phraya Dam in Chainat province, $100 \mathrm{~km}$ downstream, is approximately 2,320 $\mathrm{m}^{3} / \mathrm{sec}$. The discharge amount at Nakhon Sawan province is the key indicator station for the flood management action. The flood risk increases significantly if the discharge at this station is exceed $3,000 \mathrm{~m}^{3} / \mathrm{sec}$.

\subsection{The Geologic setting}

Our study, both the Lower Ping and the Chao Phraya Catchments, are mostly situated within this Central Plain with some part of the Lower Ping River Catchment in the Western mountain ranges. The eastern and western margins of the Central Plain are bounded by mountain ranges with associated terraces and alluvial fans. The Central Plain is divided into upper and lower parts. The Upper Central Plain originates from where the Ping, Wang, Yom and Nan Rivers join to form the Chao Phraya River in, Nakhon Sawan Province. Around this confluence several monadnocks scatter over the plain. The Chao Phraya River and its tributaries created the broad depositional surface with its well-defined meander belts forming the Lower Central Plain which is generally a flat and featureless plain spreading out southward to the Gulf of Thailand [55]. In this study, we have emphasized more on the geology of the Quaternary deposits than the Pre-Quaternary rock units since most of the catchment areas cover mainly the Central Plain which overlain mostly by the Quaternary deposits. Figure 3 is the geologic map showing simplified geology of the Central Plain and the surrounding areas which is combined and modified from various previous works [55-57].

The western part of Lower Ping River catchment consists of the mountain ranges comprising variety of rock types. Not only exposures of sedimentary and metamorphic rocks crop out, this area also comprises of exposed granitoid rocks. These granitoid rocks belong to the Western Granitoid Belts which formed in Late Cretaceous to Middle Tertiary (80-50 Ma) [58]. Since the catchment situates in the tropical and monsoon area and about onethird of the mountainous area is granitoid rocks, we can expect a high weathering soil profile and easily erodible source areas which can yield enormous amount of sand and gravel into the Lower Ping River. The eastern part of the catchment covers transitional zone between the mountain ranges and the Central Plain. It consists of mostly the terrace and alluvial fan deposits with a narrow zone of fluvial deposit along the Lower Ping River. Because of the high rate of weathering in the dominating tropical climate, the terrace deposits are not well preserved. However, remnants of terraces may still be distinguished from the floodplain as undulating gravel terrains with fragments of wellpreserved petrified wood in places [57].

The Chao Phraya River catchment is situated in the Lower Central Plain. The Quaternary deposits of the Lower Central Plain consists of a complex and very thick sequence of alluvial, fluvial and deltaic sediments. About 2,000 m of Pleistocene and Holocene sediments were deposited in the basin [59]. The general Quaternary stratigraphy of the Lower Central Plain has been compiled mainly during the groundwater and petroleum surveys. The upper $600 \mathrm{~m}$ of these unconsolidated deposits are subdivided into eight aquifers separated by thick confining clay or sandy clay layers [60]. The top most of the Lower Central Plain is the soft marine clay known as "Bangkok clay" with thickness of a few meters to $30 \mathrm{~m}$ thick in the Bangkok area. It is a part of the deposit succession of "the Chao Phraya Delta Deposits". The Chao Phraya Delta formation was sensitive to the fluctuation of the climate and sea level; and its complete succession includes both the Late Pleistocene and Holocene sequences [61]. The Chao Phraya delta extends southward from the fluvial deposits around Chainat Province to the marine deposits toward the Gulf of Thailand. Based on lithology and morphology, the delta is dominated by both fluvial and tidal processes. The stiff clay sequence is interpreted as a floodplain deposit with sandy deposits as the products of the channel migration during the Late Pleistocene regression. Overall, floodplain and levee deposits of fluvial cover the upper part and the tidal flat deposits cover the lower part of the Central Plain, whereas alluvial fans and terraces formed at the plain margins. The Pre-Quaternary geology of the Central Plain and vicinity areas consists of basement and Tertiary rocks. The basement topography is very irregular with the relief varying from 500 to $3,000 \mathrm{~m}$ [59]. They are mainly composed claystone, siltstone, sandstone and conglomerate, and overlain by Quaternary sediments deposited of the Chao Phraya River [62]. 


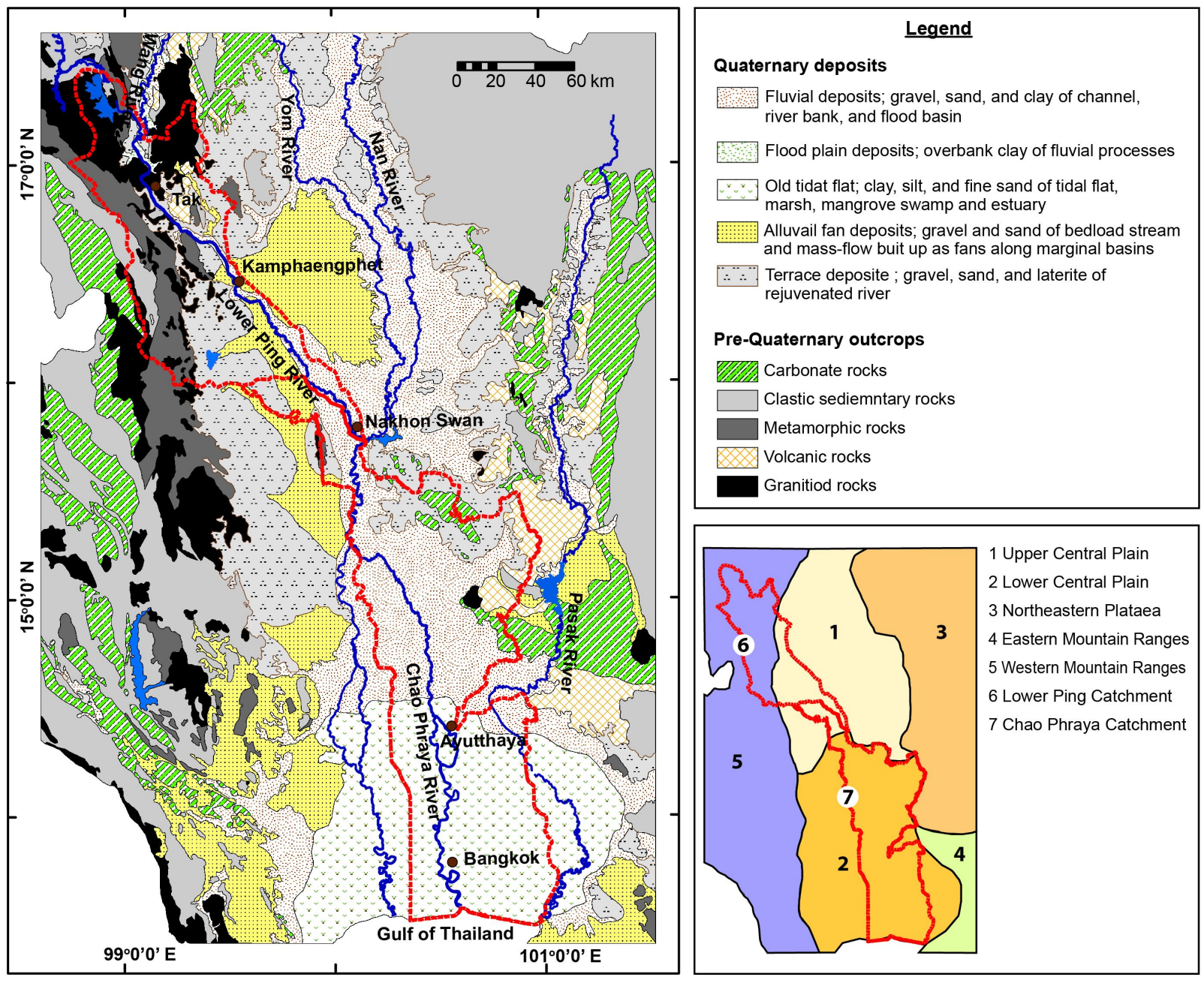

Figure 3: The geologic setting of the Central Plain of Thailand, and the surrounding areas.

\section{Results}

Landsat images show that the Lower Ping and Chao Phraya Rivers have undergone significant changes in river geomorphology overtime. The river embayment area of each reach increased and decreased during various periods, corresponding to the changes in the sand bar and island deposited along the river and also river banks erosion. Figure 4 shows some characteristics of sand bar deposited in the Lower Ping River. Changes in rivers morphology and sand bars derived from satellite images are presented in Figures 5-7 and Table 2, the coastal erosion in Figure 8 and Table 3. The detail results are described below.

\subsection{Reach 1: Downstream from the Lower Mae Ping (LMP) Dam}

This reach is the lower portion of the Ping River downstream from the Bhumibol Dam, which located at a coordinate of $17^{\circ} 14^{\prime} 33^{\prime \prime} \mathrm{N}$ and $98^{\circ} 58^{\prime} 20^{\prime \prime}$ E. The LMP Dam constructed in 1991, $5 \mathrm{~km}$ downstream from the Bhumibol Dam to provide more hydropower generation capacity to the power system. This river passes through the high terrains of granitoid rocks in Tak province. The recent length of this reach is about $126 \mathrm{~km}$ with the average width of $340 \mathrm{~m}$. The recent channel slope of this reach is 0.00051 $\mathrm{m} / \mathrm{m}$ (Table 2). It has the highest channel slope among other reaches in this study. During the study period, the mean river width of both the Lower Ping and Chao Phraya Rivers varies from a minimum of $123 \mathrm{~m}$ in Reach 4 to a maximum of $437 \mathrm{~m}$ in Reach 1 (Figure 5 and Table 2). The maximum mean river width of $437 \mathrm{~m}$ in Reach 1 was in 1987. After that, the reach began to narrow with varying rates 

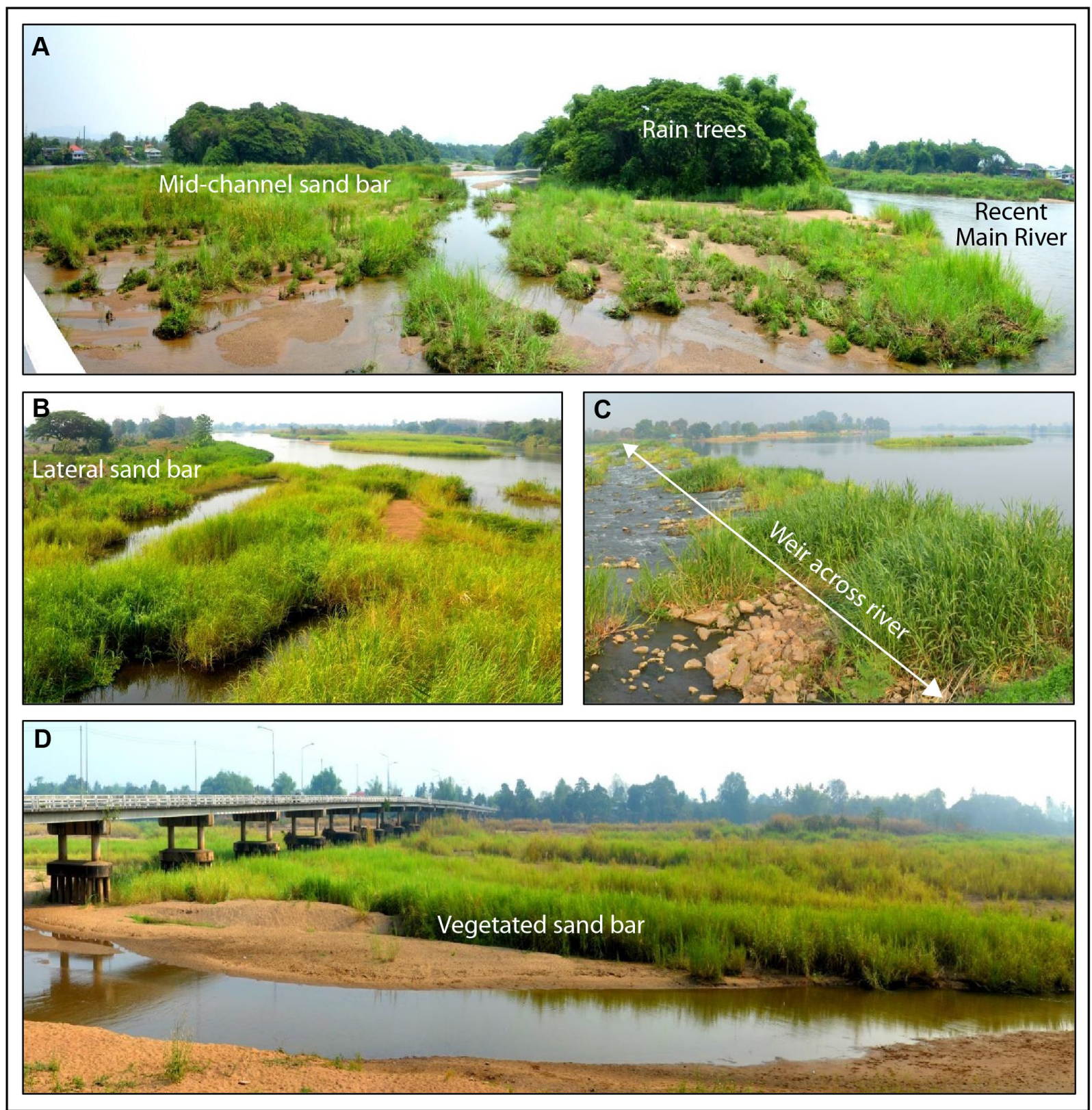

Figure 4: Characteristics of sand bars deposited in the Lower Ping River. (A) Downstream view of the Lower Ping River immediately below the Ban Tak Bridge. (B) Downstream view of sand bars the Lower Ping River immediately below the Thammarong Bridge. (C) An example of the temporally weir built across the Lower Ping River, view is on the west. (D) Downstream view along the Lower Ping River immediately below the Thap Na Khon Tri Truing Bridge. Note vegetation encroachment onto sand bars and inside channels.

until 2017. The final mean width in 2017 of Reach 1 was 340 $\mathrm{m}$, decreased by $97 \mathrm{~m}$, or a decrease of $28.5 \%$ since 1987. Reaches 1 were least sinuous with average 30 years sinuosity of about 1.32. Since 1987, this reach has become nearly straight and its sinuosity was 1.26 . Then the sinuosity has significantly increased by $9.7 \%$ to 1.39 in 1997 , but then the sinuosity has gradually and slightly decreased from 1997 to 2017. The whole sand bar area in Reaches 1 had significantly increased from 1987 to 2017. The total area of mid- channel bars (islands) was $13.58 \mathrm{~km}^{2}$ in 1987 and increased up to $15.97 \mathrm{~km}^{2}$ in 2017. Whereas the point/lateral bars area had increased from $1.98 \mathrm{~km}^{2}$ to $15.68 \mathrm{~km}^{2}$ in 2017 , which is accounted for an increase of $87.4 \%$ since 1987 . The increasing rate of the total sand bar in the Reach 1 during 1987-1997, 1997-2007, and 2007-2017 were $+0.35,+0.50$, and $+0.76 \mathrm{~km}^{2} /$ year respectively. In 2017, the total sand bar area was $31.65 \mathrm{~km}^{2}$ which is accounted for an increase of $50.8 \%$ since 1987. 
Table 2: Channel characteristics and sand bar surface areas of all reaches calculated from 1987 to 2017.

\begin{tabular}{|c|c|c|c|c|c|c|c|c|}
\hline Reach & Year & $\begin{array}{c}\text { River } \\
\text { length }(\mathrm{km})\end{array}$ & $\begin{array}{c}\text { Mean river } \\
\text { width }(\mathrm{m})\end{array}$ & $\begin{array}{l}\text { River slope } \\
(\mathrm{m} / \mathrm{m})\end{array}$ & Sinuosity & $\begin{array}{l}\text { Mid-channel } \\
\left(\mathrm{km}^{2}\right)\end{array}$ & $\begin{array}{c}\text { Point/lateral } \\
\left(\mathrm{km}^{2}\right)\end{array}$ & $\begin{array}{c}\text { Total sand } \\
\text { bar }\left(\mathrm{km}^{2}\right)\end{array}$ \\
\hline \multirow{4}{*}{ 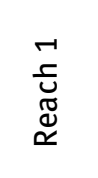 } & 1987 & 121.71 & 437.22 & 0.000526 & 1.26 & 13.58 & 1.98 & 15.56 \\
\hline & 1997 & 134.77 & 366.97 & 0.000475 & 1.39 & 13.16 & 5.85 & 19.01 \\
\hline & 2007 & 129.76 & 349.57 & 0.000493 & 1.34 & 15.40 & 8.65 & 24.05 \\
\hline & 2017 & 125.64 & 340.15 & 0.000509 & 1.30 & 15.97 & 15.68 & 31.65 \\
\hline \multirow{4}{*}{ 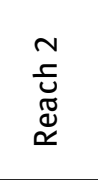 } & 1987 & 128.86 & 338.71 & 0.000342 & 1.33 & 12.46 & 3.45 & 15.91 \\
\hline & 1997 & 128.97 & 314.60 & 0.000341 & 1.33 & 11.35 & 5.50 & 16.85 \\
\hline & 2007 & 131.10 & 284.30 & 0.000336 & 1.36 & 9.15 & 9.51 & 18.66 \\
\hline & 2017 & 131.24 & 190.92 & 0.000335 & 1.36 & 5.98 & 22.65 & 28.63 \\
\hline \multirow{4}{*}{ 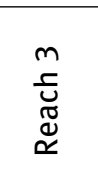 } & 1987 & 129.02 & 237.36 & 0.000139 & 1.72 & 3.13 & 2.89 & 6.02 \\
\hline & 1997 & 130.06 & 248.95 & 0.000138 & 1.73 & 2.76 & 1.49 & 4.25 \\
\hline & 2007 & 132.75 & 218.64 & 0.000136 & 1.77 & 2.98 & 2.32 & 5.31 \\
\hline & 2017 & 131.50 & 197.07 & 0.000137 & 1.75 & 2.28 & 5.36 & 7.64 \\
\hline \multirow{4}{*}{ 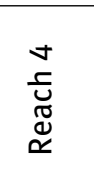 } & 1987 & 119.91 & 147.28 & 0.000067 & 1.42 & 0.12 & 1.36 & 1.48 \\
\hline & 1997 & 127.06 & 135.58 & 0.000063 & 1.51 & 2.15 & 1.36 & 3.51 \\
\hline & 2007 & 121.69 & 125.30 & 0.000066 & 1.44 & 0.00 & 2.20 & 2.20 \\
\hline & 2017 & 123.43 & 122.84 & 0.000065 & 1.46 & 0.09 & 2.58 & 2.67 \\
\hline \multirow{4}{*}{$\begin{array}{l}\tilde{L} \\
\mathcal{L} \\
\mathbb{J} \\
\stackrel{\leftrightarrow}{\alpha}\end{array}$} & 1987 & 171.72 & 331.53 & 0.000035 & 1.68 & 1.93 & 0.00 & 1.93 \\
\hline & 1997 & 203.27 & 295.45 & 0.000030 & 1.99 & 0.00 & 2.72 & 2.72 \\
\hline & 2007 & 182.49 & 313.54 & 0.000033 & 1.79 & 3.85 & 2.72 & 6.57 \\
\hline & 2017 & 192.97 & 301.44 & 0.000031 & 1.89 & 1.73 & 2.19 & 3.92 \\
\hline
\end{tabular}

Table 3: Changes in the Chao Phraya deltaic area indicating coastal erosion and deposition during the period 1987-2017.

\begin{tabular}{|c|c|c|c|c|c|}
\hline $\begin{array}{l}\text { Coastal } \\
\text { Area }\end{array}$ & Year & $\begin{array}{l}\text { Erosional area } \\
\qquad\left(\mathrm{km}^{2}\right)\end{array}$ & $\begin{array}{l}\text { Erosional rate } \\
\left(\mathrm{km}^{2} / \mathrm{yr}\right)\end{array}$ & $\begin{array}{l}\text { Depositional area } \\
\left(\mathrm{km}^{2}\right)\end{array}$ & $\begin{array}{c}\text { Depositional rate } \\
\left(\mathrm{km}^{2} / \mathrm{yr}\right)\end{array}$ \\
\hline \multirow{4}{*}{ 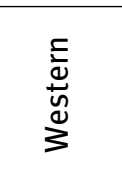 } & 1987-1997 & -3.36 & -0.34 & 0.54 & 0.05 \\
\hline & $1997-2007$ & -5.14 & -0.51 & 0.32 & 0.03 \\
\hline & 2007-2017 & -2.62 & -0.26 & 0.25 & 0.03 \\
\hline & $1987-2017$ & -11.13 & -0.37 & 1.12 & 0.04 \\
\hline \multirow{4}{*}{ 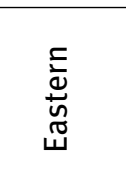 } & 1987-1997 & -3.39 & -0.34 & 0.52 & 0.05 \\
\hline & 1997-2007 & -3.20 & -0.32 & 0.57 & 0.06 \\
\hline & $2007-2017$ & -1.12 & -0.11 & 1.18 & 0.12 \\
\hline & $1987-2017$ & -7.71 & -0.26 & 2.27 & 0.08 \\
\hline \multirow{4}{*}{ 离 } & 1987-1997 & -6.76 & -0.68 & 1.05 & 0.11 \\
\hline & $1997-2007$ & -8.34 & -0.83 & 0.90 & 0.09 \\
\hline & 2007-2017 & -3.74 & -0.37 & 1.43 & 0.14 \\
\hline & $1987-2017$ & -18.84 & -0.63 & 3.38 & 0.11 \\
\hline
\end{tabular}

\subsection{Reach 2: The Lower Mae Ping Weir project area}

The Reach 2 starts from the first weir (Weir \#1) located at the upper most upstream of the succession of weir (latitude $16^{\circ} 30^{\prime} 11^{\prime \prime} \mathrm{N}$ and longitude $99^{\circ} 29^{\prime} 42^{\prime \prime} \mathrm{E}$ ). At present, there are seven weirs distributed along the Lower Ping River within this reach. The Reach 2 ends at the last weir downstream (Weir \#7), before the Ping-Nan confluence at the Pak Nam Poh (latitude 15 49' 47" N and longitude $100^{\circ}$ 4' 29" E) in Nakhon Sawan Province. The weirs have been built within this reach in order to raise the river water level and diverse the water for irrigation purpose. The direct effect of weir is increasing sediment deposition and formation of sediment wedge behind them [47]. The recent channel length of this reach is $131 \mathrm{~km}$, with the average width 


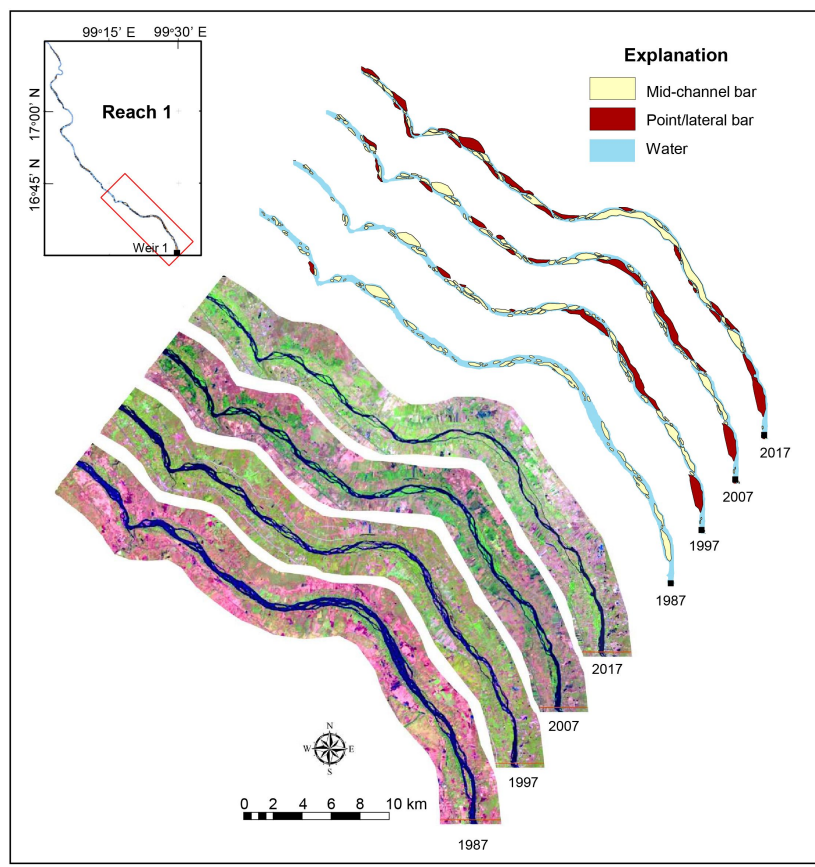

Figure 5: Detection of channel dynamic of the Lower Ping River near the end of Reach 1 above the $1^{\text {st }}$ weir of the Lower Mae Ping Weir Project.

of $191 \mathrm{~m}$, and the recent channel slope of $0.00034 \mathrm{~m} / \mathrm{m}$. Reach 2 shows the most significant change in the river width (Figure 6). The most narrowing rate of the Lower Ping River has also been observed in this reach. The average river width was $339 \mathrm{~m}$ in 1987, then narrowing to only $191 \mathrm{~m}$ in 2017. This accounts for a decrease of $77.4 \%$ since 1987. Especially, during the last decade (from 2007-2017), the average river narrowing rate was about $9 \mathrm{~m} /$ year and by that the average width of the river had decreased about $93 \mathrm{~m}$. The Reaches 2 had slightly changes in sinuosity, the sinuosity had maintained throughout the study period at averagely about 1.34 . The total area of the (islands) was $12.46 \mathrm{~km}^{2}$ in 1987 . Then, the area had gradually decreased to $5.98 \mathrm{~km}^{2}$ in 2017. On the contrary, the point/lateral bars had dramatically increased about $19.2 \mathrm{~km}^{2}$ (84.8\%) from 3.45 to $22.65 \mathrm{~km}^{2}$ since 1987. The average areal increasing rate of the total sand bar in Reach 2 is $0.42 \mathrm{~km}^{2} /$ year during this study time span. The decreasing of mid-channel bars in the Reach 2 is normal, as small sand bars tend to grow or merge into larger islands within the river embayment, or as point or lateral bars attached to river banks through time. The increasing rate of the total sand bar in the Reach 2 during 1987-1997, 1997-2007, and 2007-2017 were $+0.09,+0.18$, and $+1.00 \mathrm{~km}^{2} /$ year respectively. In 2017 , the total sand bar area was $28.63 \mathrm{~km}^{2}$ which is accounted for an increase of $44.4 \%$ since 1987 . Overall, approximately $28.81 \mathrm{~km}^{2}$ of sand bar surface had accumulated within the Reaches 1

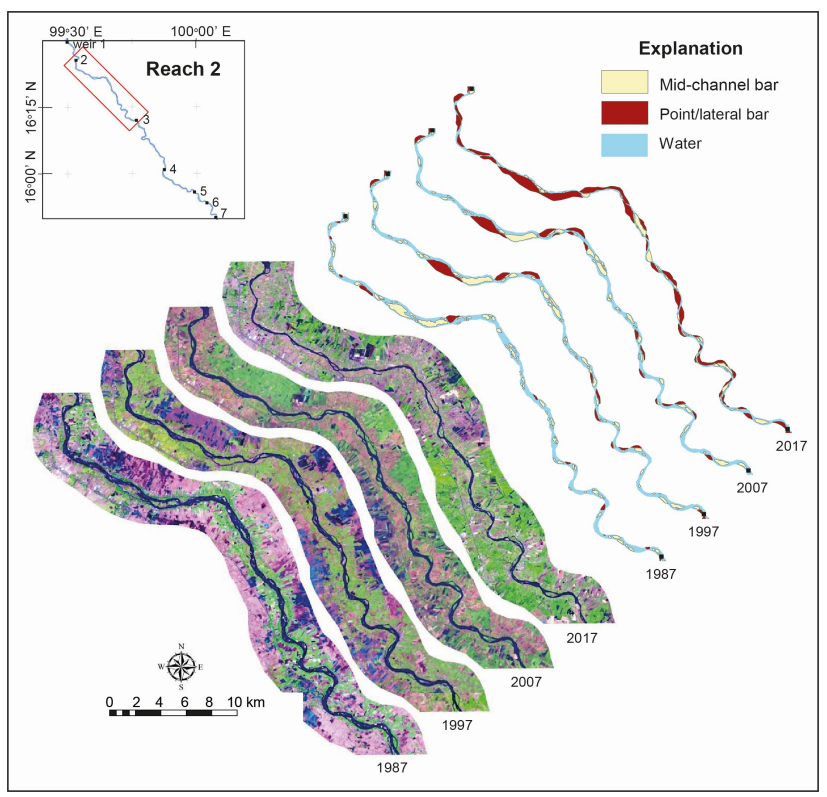

Figure 6: Sequential changes in the planform of the Lower Ping River over 30 years period. Series of Landsat images show the sand bars had been increasing progressively from 1987 onwards in Reach 2.

and 2 combined along the Lower Ping River downstream from 1987 to 2017.

\subsection{Reach 3: The upstream from Chao Phraya (CPY) Dam}

The Reach 3 continues further downstream from the end of Reach 2 passing through "Pak Nam Poh", the Ping-Nan confluence, which the confluence point is the beginning of the Chao Phraya River and ends at the CPY Dam (latitude $15^{\circ} 9^{\prime} 33^{\prime \prime} \mathrm{N}$ and longitude $100^{\circ} 10^{\prime} 47^{\prime \prime} \mathrm{E}$ ). The recent channel length of this reach is approximately $132 \mathrm{~km}$, and the average width is $197 \mathrm{~m}$. The channel slope of this river reach declines gradually with an average channel slope at $0.00014 \mathrm{~m} / \mathrm{m}$. This river reach flows through the lowlands of the Central Plain. There are no more weirs within this reach. However, at the lower portion of the reach, the river water level has been raised higher, as it is part of the backwater zone of Dam which situated at the end of the reach. The main purpose of the CPY Dam is for irrigation and to reduce the chance of flooding in the downstream area by controlling the water discharge and diverting it through irrigation canals. However, the operation of the CPY Dam by reducing discharge downstream (i.e. increasing backwater zone upstream) combine with peak flows released from dams upstream during the flooding period can induce flooding over the upstream area of the dam. The dam 
can trap and reduce the great amount of sediment downstream which will accelerate the degradation process of the river course downstream. The reservoir or backwater zone above the Chao Phraya Dam also reduces the deposition within the zone especially the deposition of bedload sediment i.e. deposition of sand bars. The operation of Chao Phraya Dam can create the backwater and affects the Chao Phraya River and its tributaries (the Ping River and the Nan River) as far as 110 kilometers upstream [63]. The narrowing trend of the Lower Ping and Chao Phraya Rivers is also detected in this reach. The changes of the average river width from $237 \mathrm{~m}$ to $197 \mathrm{~m}$ (20.4\%) during 1987-2017 was detected. The sinuosity had maintained throughout the study period at averagely about 1.74 . Table 2 shows the changes of sand bar area along this river reach. The changing rate of the total sand bar area in the Reach 3 during 1987-1997, 1997-2007, and 2007-2017 were -0.18, +0.11, and $+0.23 \mathrm{~km}^{2} /$ year respectively. In 2017, the total sand bar area was $7.64 \mathrm{~km}^{2}$ which is accounted for an increase of $21.2 \%$ since 1987.

\subsection{Reach 4: The downstream from the CPY Dam}

This reach starts from below the CPY Dam and flows through the central plains of the Chao Phraya Basin. This river reach ends at the point where the Chao Phraya River splits into two channels at latitude $14^{\circ} 26^{\prime} 51^{\prime \prime} \mathrm{N}$ and longitude $100^{\circ} 27^{\prime} 34^{\prime \prime} \mathrm{E}$ in Ayutthaya Province. The recent channel length of this reach is approximately $123 \mathrm{~km}$, and the average width is $123 \mathrm{~m}$. The present average channel slope of the Chao Phraya River within this reach is $0.000065 \mathrm{~m} / \mathrm{m}$. The obvious impact of this reach is sediment depletion as mentioned earlier that most of bedload sediment is trapped within the upper reaches. This condition of sediment supply less than transportation capacity leads to erosion either on the river bed and/or river banks. Furthermore, in the past intense in-channel sand mining had been recorded along this river reach. Sand mining may be also another major cause that accelerates the river banks erosion/collapsing rate. The narrowing trend of the Chao Phraya River is also detected in this reach (Figure 7). The average river width had changed from $147 \mathrm{~m}$ to $123 \mathrm{~m}$ (19.9\%) during 1987-2017. Although, the upstream reaches (Reaches 1-3) had maintained their sinuosity, the Chao Phraya River in Reach 4 shows dramatically changes in sinuosity, the sinuosity was 1.42 in 1987 , and then 1.51 in 1997. Then, it decreased back to 1.44 thereafter. The changing rate of the total sand bar area in the Reach 4 during 1987-1997, 1997-2007, and 2007-2017 were $+0.20,-0.13$, and
$+0.05 \mathrm{~km}^{2} /$ year respectively. In 2017, the total sand bar area was $2.67 \mathrm{~km}^{2}$ which is accounted for an increase of $44.6 \%$ since 1987.

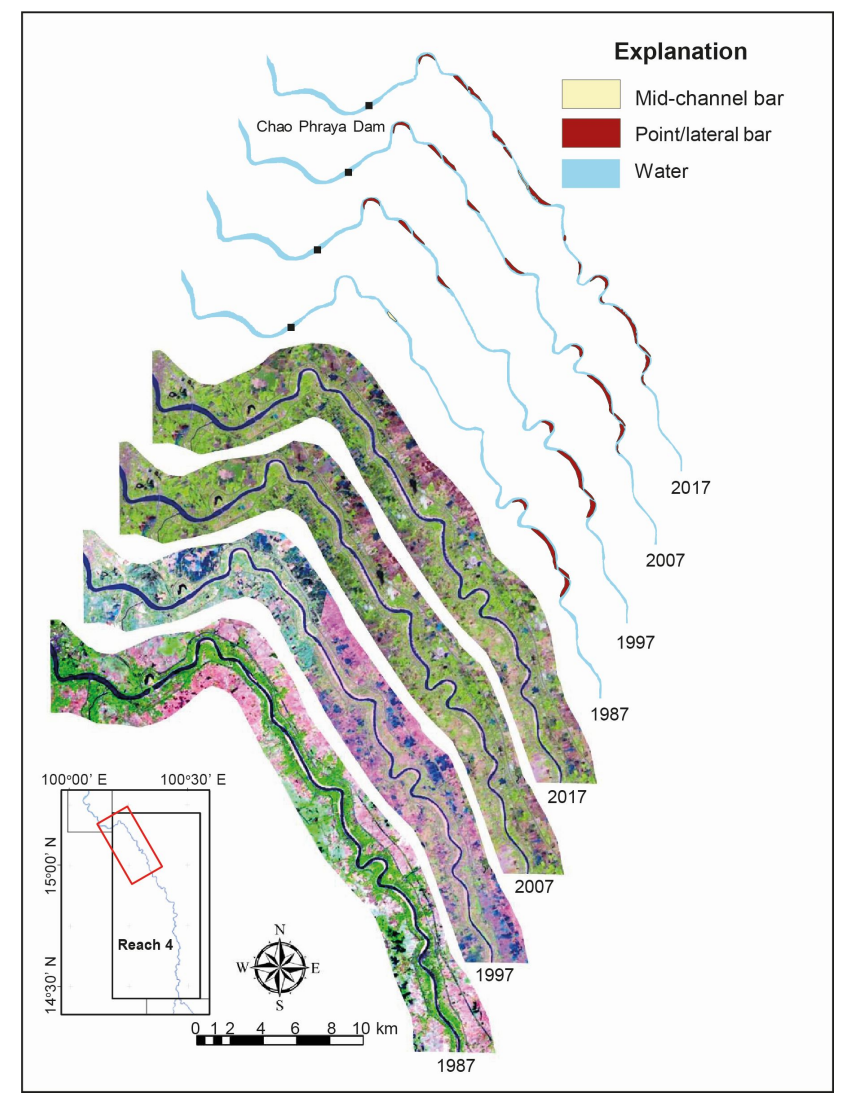

Figure 7: Landsat imageries of the Chao Phraya River downstream from the Chao Phraya Dam.

\subsection{Reach 5: The lowest channel slope of CPY River}

This is the last reach of the Chao Phraya River. It flows through the central plains to the Chao Phraya River mouth, and enters the Gulf of Thailand around latitude $13^{\circ} 31^{\prime} 52^{\prime \prime}$ $\mathrm{N}$ and longitude $100^{\circ} 36^{\prime} 00^{\prime \prime} \mathrm{E}$. The length of the Chao Phraya River of this reach is $193 \mathrm{~km}$ and the average width is $301 \mathrm{~m}$. This river reach has the lowest channel slope among all reaches. The present average channel slope of the Chao Phraya River within this reach is $0.00003 \mathrm{~m} / \mathrm{m}$. At the beginning of the reach, in Ayutthaya Province, the river splits into two channels, making them narrower than the one upstream. Then the two channels join again, and the river gains its normal width and gets wider downstream. Since the river in this reach passes through several ma- 


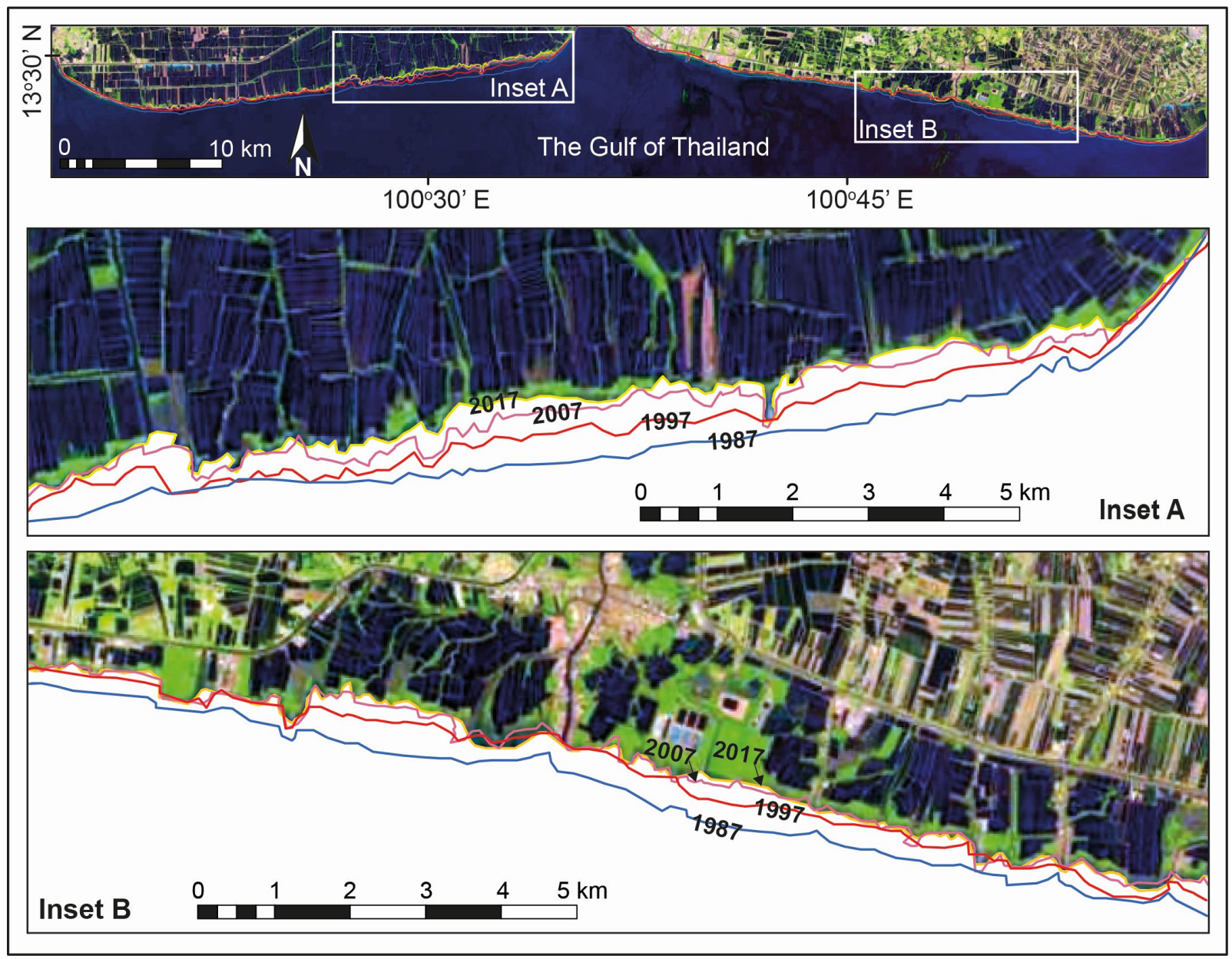

Figure 8: Coastal erosion in the Chao Phraya Delta during the period 1987-2017 observed from Landsat imageries. Inset A cover the western part and inset $B$ is in the eastern part.

jor city including Bangkok, the embanked protecting has been most applied compare to the other reaches. The intensity of the river bank protection may be another factor that alter the dynamic of the river. Reach 5 also shows the slightly narrowing trend of the Chao Phraya River. The river changed from $332 \mathrm{~m}$ to $301 \mathrm{~m}$ wide (10\%) since 1987. From this study, the widening trend of the river has been observed in only 2 intervals of the Lower Ping and Chao Phraya Rivers, during 1987-1997 in the Reach 3 and 19972007 in Reach 5. The most significant change in sinuosity occurred in the this lower most reach, the sinuosity changed severely by $15.5 \%$ from 1.68 in 1987 to 1.99 in 1997. Then the river decreased its sinuous back to 1.79 in 2007, and then again increased to 1.89 thereafter in 2017. The average sinuosity of the Reach 5 during this study period is 1.84 considered as the highest sinuosity, i.e. the most meandering river reach among all 5 reaches of this study. The changing rate of the total sand bar area in the Reach 5 during 1987-1997, 1997-2007, and 2007-2017 were $+0.80,+0.39$, and $-0.27 \mathrm{~km}^{2} /$ year respectively. In 2017, the total sand bar area was $2.67 \mathrm{~km}^{2}$ which is accounted for an increase of $44.6 \%$ since 1987.

\subsection{Coastal area around the Chao Phraya Delta}

This study also assesses the spatial change at the Chao Phraya deltaic zone. The Chao Phraya deltaic zone in this study was subdivided into 1) the Western Chao Phraya Delta Coast and 2) the Eastern Chao Phraya Delta Coast. The Western Chao Phraya Delta coast is the coastline stretching from the Chao Phraya River mouth and continues westward to the Tha Chin River mouth, and the Eastern Chao Phraya Delta coast is the coastline between the Chao Phraya River and the Bang Pakong River mouths (Figure 8 and Table 3). The analysis based on coastline positions of each period between 1987 and 2017 indicates a 
substantial coastal change in the Chao Phraya deltaic zone during this past 30 years. The results show that the Western Chao Phraya Delta Coast had lost $3.36 \mathrm{~km}^{2}$ during the first decade of this study from 1987-1997, then it had experienced more degree of recession during the second pe$\operatorname{riod}(1997-2007)$ and lost $5.14 \mathrm{~km}^{2}$ of the coastal area. However, during the last period of this study from 2007-2017 the coastal recession has declined, and the land lost was only $2.62 \mathrm{~km}^{2}$. The erosional rate of the Western Chao Phraya Delta coast during 1987-1997, 1997-2007, and 2007-2017 were $0.34,0.51$, and $0.26 \mathrm{~km}^{2} /$ year respectively. The total erosion of the Western Chao Phraya Delta Coast area was approximately $11 \mathrm{~km}^{2}$ during $1987-2017$. On the contrary, the deposition along Western Chao Phraya Delta Coast was quite low. The area of coastal deposition was much less than coastal erosion with the average deposition rate of $0.04 \mathrm{~km}^{2} /$ year and only $1.12 \mathrm{~km}^{2}$ of the net deposition areas has been detected within the 30 years.

During 1987-1997, both the Eastern and Western Chao Phraya Delta Coasts show similar shoreline change patterns, and also the degrees of erosion and deposition. The Eastern Chao Phraya Delta Coast had eroded $3.39 \mathrm{~km}^{2}$ during 1987-1997. Then, the east coastal areas lost were 3.20 $\mathrm{km}^{2}$ during 1997-2007 and $1.12 \mathrm{~km}^{2}$ during 2007-2017 showing declining trend of erosion. The erosional rate of the Eastern Chao Phraya Delta coast during 1987-1997, 19972007, and 2007-2017 were $0.34,0.32$, and $0.11 \mathrm{~km}^{2} /$ year respectively. The total erosion of the Eastern Chao Phraya Delta Coast area was approximately $8 \mathrm{~km}^{2}$ from 1987 to 2017. Unlike the west coast, the east coast deposition rate had increased during three decades with a net deposition area of $2.27 \mathrm{~km}^{2}$. Nevertheless, the magnitude of coastal area growth is still significantly less than the area of recession. The average deposition rate on the east coast was $0.05 \mathrm{~km}^{2} /$ year during 1987-1997 and $0.06 \mathrm{~km}^{2} /$ year during 1997-2007, and then increased 2 times up to 0.12 $\mathrm{km}^{2}$ /year during 2007-2017. Overall, approximately 18.84 $\mathrm{km}^{2}$ of coastal areas around the Chao Phraya Delta had been eroded during 1987-2017, and the total erosional rate of the delta coast (both Eastern and Western Coasts) during 1987-1997, 1997-2007, and 2007-2017 were 0.68, 0.83, and $0.37 \mathrm{~km}^{2} /$ year, respectively.

\section{Discussion}

\subsection{Factors driving morphodynamical changes of the Lower Ping and Chao Phraya Rivers}

The dynamics of the Lower Ping River downstream from the LMP Dam and the Chao Phraya River detected from 1987 to 2017 result in changes in the river width, the formation and removal of sand bars, and river banks erosion. The most substantial geomorphological changes from this study were the decreasing of river width in Reaches 1 and 2 of the Lower Ping River. Only the Reach 5 shows increasing of the river width during three decades of this research. The upper reaches (the Lower Ping River) in this study were wider than the lower reaches (the Chao Phraya River) throughout the four periods of the study. Reach 1 had the highest average mean river width, while Reach 4 had the lowest mean river width. The fact that the CPY Dam has been reducing the peak flow of the river downstream may be responsible for the narrowing of the Chao Phraya River within Reach 4.

Furthermore, the increase of sand bar areas along the rivers indicates that the upstream reaches (Reaches 1 and 2) of the Lower Ping River have experienced the aggradation stage where as the lower reach like Reach 5 has been degraded. The sand bars in the Reach 2 had been increasing progressively from 1987 onward; and had the highest increasing rate at $1.00 \mathrm{~km}^{2} /$ year during 2007-2017 (Figure 9). It coincides with the construction of "the Lower Mae Ping Weir Project" which initiated within this reach. Figure 3 illustrates that the Lower Ping River Catchment consists about one-third of granitoid rocks outcrops. These outcrops are highly weathered and relatively unstable due to high rainfall of the tropical and monsoon climate. As a result, the mountainous areas yield enormous amount of sediment supply (especially bedload) have been transported by tributaries into the Lower Ping River. There are two dams installed in the headwater of the Lower Ping River Catchment, the Bhumibol and the Lower Mae Ping Dams. Both dams have controlled and reduced peak flows of the Lower Ping River, especially the Lower Mae Ping Dam which completed later in 1991 which leading to less sediment transportation and more sedimentation along the river. These results indicate that both anthropologic and geologic factors have not impacted only the water regime but also influenced the sediment regime, which both represent fundamental elements in the river fluvial system and determine the overall morphology of a river. 


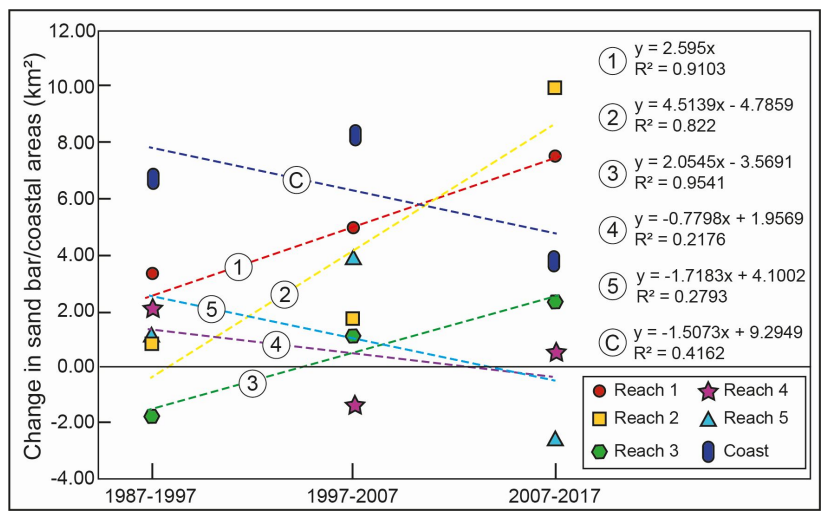

Figure 9: Graph illustrates the increasing and decreasing of sand bar areas of the Reaches 1-5 and coastal erosion area during 10 year-intervals of 1987-1997, 1997-2007 and 2007-2017. The trendlines 1-5 represent the changing trend of sand bar areas of the Reaches 1-5 respectively, and the trendline " $C$ " represent the changing trend of erosion area along the delta coast.

\subsection{Shallowing of river channel and flooding}

Recently, changing in hydraulic regime and sediment accumulation rate along the river due to regulation has been recognized and documented [64-71]. Normally, both bedload and suspended sediment will be trapped in the river and reservoir behind the dam and sediment depletion and erosion occur downstream of the dam [72-74]. However, the Lower Ping River downstream from the LMP Dam in Reaches 1 and 2 has severely suffered from the excessive sedimentation (Figure 10). These unusual dynamic changes of the Lower Ping River are due to the unique geological setting and intense river regulation along these upper reaches. Reaches 1 and 2 of the Lower Ping River from this study situate in the terrains of granitic rocks which during monsoon seasons can yield enormous sand budget into the Lower Ping River through the tributaries. In addition, the LMP Dam, which designed to provide more hydropower generation capacity, has significantly reduced the water discharge and also flow velocity of the Lower Ping River.

The Combination of high sediment supply and low water discharge can result in significant sediment deposit along the river $[75,76]$, causing the river shallowing and narrowing as observed in this study. Further downstream from Reach 1, Reach 2 has experienced the same situation. Along $131 \mathrm{~km}$ length of this Lower Ping River reach, seven weirs have been built across the river. Hence, most of the additional bedload sediment supply from tributaries would have been trapped above and between these weirs [77]. In the past all projects that involve floods control or supplying water for farmland in irrigation area are sim- ply proposed by building large dams, small reservoirs, or weirs to regulate the flow of water. For decades, the Thai government has initiated irrigation along the Lower Ping and the Chao Phraya River. These irrigation projects have provided numerous socio-economic benefits not only for agriculture in the irrigation areas, but also played the important role in flood control. In a short period, i.e. few decades, it may seem that these irrigation projects have minimal effects on river geomorphology. However, the long-term effects of river regulations are devastating and take longer time to reveal.

Another point needed to be discussed is vegetation encroachment on sand bars. As our study results show that the sediment deposition has been increasing along the Lower Ping River in this past three decades. The most important flow alteration due to regulation on the Lower Ping River is the reduction of flood magnitude. Consequently, river channels quickly stabilize, and the riparian vegetation can colonize and encroach on previously active sandbar deposits (Figures 4). This in turn promotes more sediment aggradation and growth of sandbar along the river. From our field observation, we have observed that huge and tall trees (more than 15 meters tall) like rain trees have growth on some islands (Figure 4A). This implies that the vegetation encroachment on sand bars has happened for over several decades. So, the vegetation encroachment on sand bars along the Lower Ping River is considered as another important factor promoting more sand bars construction along this river reach. It also creates difficulties for sediment management such as river dredging for flood control in the future.

\subsection{Loss of equilibrium in the deltaic zone}

Beside the geomorphological changes along the Lower Ping and Chao Phraya Rivers, changes of the Chao Phraya deltaic zone were recognized clearly from the Landsat images. The severe coastal erosion along the Chao Phraya Deltaic zone in the Upper Gulf of Thailand during the past 3 decades has been observed. The erosion of the coastal around the Chao Phraya Delta has been intensified and studied [39, 40, 78-84]. This shoreline retreat is caused by both natural processes and anthropogenic factors such as mangrove deforestation via the conversion of mangrove forest into aquacultural farmland, land subsidence along the Chao Phraya Delta and a reduction in sediment supply $[85,86]$.

In the Chao Phraya deltaic area, among the anthropogenic factors that responsible for the coastal retreat, human-induced land subsidence and a reduction in sed- 


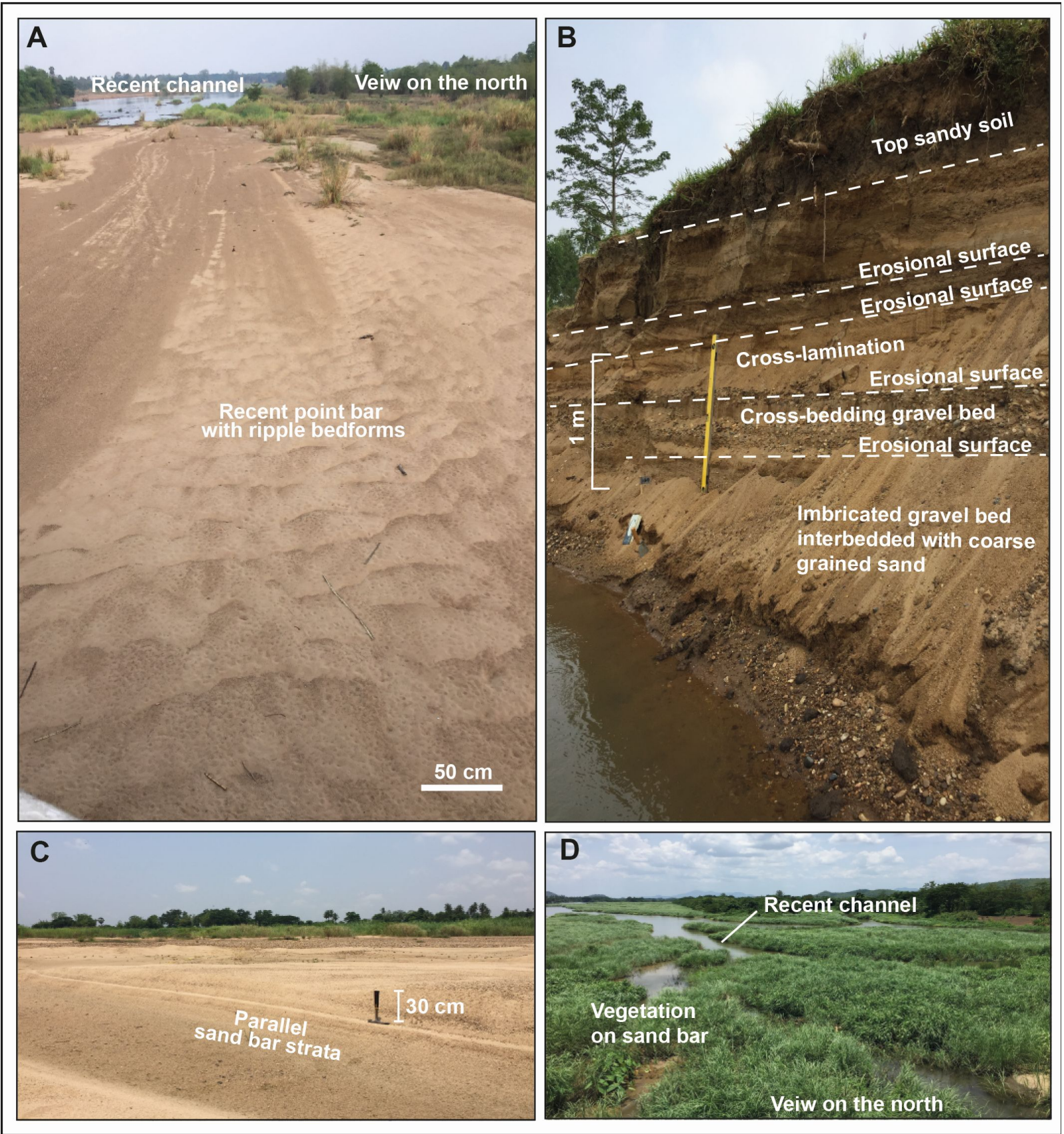

Figure 10: (A) Ripple mark bedforms on sand bar surface, (B) three meters thick of eroded sand bar deposit showing cobble and pebble beds interbedded with cross-bedding gravel bed and overlain by cross-bedding sand, (C) parallel sand bar strata (hammer as scale, view is on the west) and (D) modern vegetarian encroachment on sand bar (view is on the north).

iment supply by river regulation are well documented. The coastal erosional rate in this delta area is averagely $26 \mathrm{~m} /$ year [39]. The intensified groundwater extraction, which follows the expansion of the city of Bangkok began around 1953 and became widely used until around 1990 causing the high subsidence rate around the Chao Phraya Delta coastal zone $[39,55]$. During that time, the Chao Phraya Delta was one of the world's highest subsi- dence rate deltas, with subsidence rate ranged from 50 to $150 \mathrm{~mm} /$ year [87]. The total land subsidence in the Chao Phraya Delta coastal zone ranged from 65 to $96 \mathrm{~cm}$, the greatest subsidence concentrated around the eastern side of the Chao Phraya River mouth, which situating the Bangkok Metropolis [88]. However, the coastal retreat has been occurring on both sides of the Chao Phraya River mouth, even with a greater rate on the western deltaic 
coast than the eastern one. It is quite clear that the rapid incursion of the sea around the Chao Phraya Delta has significantly linked to land subsidence and contributed to some degree of the rapid shoreline retreat of the coastal area [57].

However, the other dominantly anthropogenic factor that cannot be neglected is the reduction in sediment supply from the river by irrigation projects. Rivers are major sediment load transportation pathways which account for more than $95 \%$ of the sediment entering the oceans $[57,89]$. River sediment loads are the main material contributing to the building of deltas and coastal zones [90]. Decreasing amount of sediment delivery to the estuaries reduces the sediment deposition rate of the deltas which in turn promoting coastal erosion [91]. Increasing of the irrigation projects over the globe has led to intensive study of the effects of dams on fluvial systems, particularly on the retreat of deltas [92-94]. Figure 9 illustrates the increasing and decreasing of sand bar areas of the Reaches 1-5 and coastal erosion area during 10 year-intervals of 1987-1997, 1997-2007 and 2007-2017. The trendlines indicate increasing trend of sand bar in the Reaches 1, 2 and 3, and decreasing trend of sand bar in Reaches 4 and 5. During the first 2 . two period (1987-1997 and 1997-2007) the increasing trends of sand bar area in the Reaches 1, 2 and 3 seem concordant with the increasing erosion area along the delta coast. Then during 2007-2017 as the sand bars in the Reaches 1-3 had continued to increase, the erosion of the coastal area had declined i.e. the erosion rate had slowed down. We believe that this is due to the success of the recent restoration and protection projects using the construction of coastline revetments, construction of detached breakwaters parallel to the coast, and replanting of juvenile mangrove trees which have been employed in the past decade.

The Lower Ping and the Chao Phraya Rivers are considered as one of the most regulated and disturbed rivers both from irrigation projects such as weirs and dams and other human activities such as river sand exploitation and river dredging. In this study, the increasing of trapped bedload sediment in the Lower Ping River can be recognized as an increasing sand bar surface area in the channel over time. Almost 30 square kilometer of sand bar, especially within the Lower Ping River has been increased during the 30 years period from 1987 to 2017. This implies that large amount of bedload sediment has been restrained within this portion of the Lower Ping River. This change in the amount and composition of transport sediment load of the Lower Ping and the Chao Phraya River has been underestimated and rarely documented, yet it may have been another crucial factor in promoting the coastal erosion around the Chao Phraya Delta.

\section{Implications}

. Construction of weir: In Thailand, weirs have been used as one of the fundamental structures to control rivers and streams for decades. They have been mainly constructed for diverting flows for irrigation purpose. This study results show obvious adverse effect of weirs, that is trapping bedload sediment behind them and hence raising riverbed upstream, especially within the high bedload sediment budget such as the Lower Ping River. Constructing new weirs needs a more careful studies of geologic conditions, location of weir correlation with tributaries, and sediment load characteristics especially bedload. Because any new weir will create a new obstruction on the river or stream and, subsequently sediment loads will be deposits filling the reservoir and raising riverbed upstream. These effects of weir may take decades to reveal and have not yet been considered or broadly studied in Thailand. As within the succession of weir, the adverse impacts on river or stream will be more problematic than only one weir itself.

Commercial Sand Mining: The Lower Ping River has trapped enormous sand and gravel. This attracts a lot of investors to apply for the in-channel sand mining lease in this area. Recently, aggregate extraction of in-channel sand mines has shifted from the Chao Phraya River, downstream from the Chao Phraya Dam, to the Lower Ping River after depletion of riverbed sand and serious banks collapsing along the Chao Phraya River. There are at least 30 sand mines distributed along the Lower Ping River. The issue of sediment mining in the Lower Ping River channel has not also been considered as a cause of morphological change and environmental impacts in the Lower Ping River yet. Although, this section of the Lower Ping River is complex because the high availability of sand and gravel. But sand and gravel resources are not renewable. This study can assist in locating suitable sites for in-channel mining. However, more attempts will be needed to quantify suitable volumes of sand and gravel that can be extracted from the Lower Ping River, and to identify sediment availability trends in this river.

. Reservoir sedimentation: The sedimentation rate of each artificial reservoir is very variable. It depends more particularly on the climatic situation, the geomorphology of the alluvial river systems, and geologic conditions of the watershed. In Thailand, over the years measurements of reservoir sedimentation rate have been carried out by the RID. However, most of the works emphasis only on suspended load sedimentation in the reservoir. Management of sedimentation in reservoirs should not be comprehended by a standard generalized rule or procedure or limited to the 
reservoir itself. It should include analytical of the catchment areas and extends to the downstream river. An integrated sediment management strategy is necessitated to balance the sediment budget across reservoir. The Lower Ping River is an excellent example of this problem. Therefore, sediment load, especially bedload monitoring and management should also include the downstream reaches as well as the upstream reaches and reservoirs. This will ensure that impoundments by dam and weir will have sustainable long-term benefits, rather than operating as a nonsustainable source of water supply.

4. Coastal erosion: The dynamic changes of the upstream fluvial will also affect the dynamics of the coastal area surrounding the river mouth. This study shows the relation between trapped sediment load upstream and depletion of sediment load downstream which leading to substantial erosion of the coastal area. As mentioned above that the severe coastal erosion in the Upper Gulf of Thailand during past decades may have been produced by several factors. Damming is assumed to be a major factor responsible for decreasing of sediment loads to the delta system, leading to rapid coastal erosion [83, 87]. From our study, it seems that the coastal erosional rate had been decreased, indicating that the restoration and protection projects along the coast line have successfully slowed down the erosional process. However, the coastal erosion will remain a persistent problem in this area, if the enormous amount of sediment load continues to be trapped within the fluvial system upstream.

\section{Conclusions}

The Lower Ping and Chao Phraya Rivers are the major rivers of the Chao Phraya River Basin, one important lowlying plain in Southeast Asian countries. Geomorphology of both rivers has changed dramatically and unusually in some senses. The change with one decadal interval in river embankment and loss of equilibrium in recent deltaic zone derived from Landsat imageries in 1987, 1997, 2007 and 2017 are concluded as follows.

1. During the past three decades, the results from Landsat images interpretation indicate that river embayment areas had decreased in Reaches 1, 2, 3 and 4, whereas Reach 5 shows slightly increasing trend. The decreasing trend of river embayment area is also reflected the narrowing trend of the river in those reaches of the Lower Ping and Chao Phraya Rivers. The total decreasing of the river embayment area of Reach 1 is $10.5 \mathrm{~km}^{2}$ (24.5\%) since 1987. Reach 2 shows the most significant change in the river embayment area compare to other reaches, with the total decreasing area of $18.6 \mathrm{~km}^{2}$ (74.2\%) since 1987.

2. The total sand bar area (both mid-channel and point/lateral bars) deposited along the Lower Ping River had the most significant increase from 1987 to 2017 in Reaches 1 and 2. Within Reach 1, the increasing of total sand bar area was $16.1 \mathrm{~km} 2$ (50.8\%). As for Reach 2, the Lower Ping River within the "Lower Mae Ping Weir Project", the increasing of total sand bar area was $12.7 \mathrm{~km}^{2}$ (44.4\%). It suggested that both geological conditions and anthropogenic activities are the main factors that responsible for these geometry changes of both rivers.

3. The downstream reach of the Chao Phraya River and the coastal area around its delta have experienced the significant erosion. Approximate $18.8 \mathrm{~km}^{2}$ of the coastal areas both from the western and eastern sides of the Chao Phraya Delta have been eroded since 1987. From this study, it can be assumed that the excessive trapped bedload sediment along the upper reaches maybe responsible for the significant erosion of the lower reaches and the coastal area around the Chao Phraya River delta.

4. The application of remote sensing and GIS from this study demonstrates an efficient way to determine river geomorphology dynamic and understand how geological setting and human activities influence them. The results from this study will accommodate for further planning of the rivers in term of flood control and irrigation management.

Author contributions: This research was carried out with the collaboration of all authors. NC, first author, was involved in geological field survey, sampling, computerizing of GIS software and writing draft manuscript. PN, second author, was involved in editing and revising the manuscript. MC, corresponding author, involved in planning and supervision of the work, editing and revising the manuscript.

Acknowledgement: The $90^{\text {th }}$ Anniversary of Chulalongkorn University, Ratchadapisek Somphot Endowment Foundation provided fund to NC. National Research Council of Thailand (NRCT) sponsored research funding to MC via Agricultural Research Development Agency (Public Organization), (ARDA). 


\section{References}

[1] Capelli, G., Miccadei, E., Raffi, R.. Fluvial dynamics in the Castel di Sangro plain: morphological changes and human impact from 1875 to 1992 . Catena, 1997, 30, 295-309.

[2] Mossa, J., Mc Lean, M. Channel planform and land cover change on a mine driver floodplain. Appl Geogr, 1997, 17, 43-54.

[3] Surian, N. Channel changes due to river regulation: the case of the Piave River, Italy. Earth Surf Process Landf, 1999, 24, 1135 1151.

[4] Rinaldi, M. Recent channel adjustments in alluvial rivers of Tuscany, Central Italy. Earth Surf Process Landf, 2003, 28, 587-608.

[5] Surian, N. and Rinaldi, M. Morphological response to river engineering and management in alluvial channels in Italy. Geomorphology, 2003, 50, 307-326.

[6] Chin, A., Gregory, K.J. Managing urban river channel adjustments. Geomorphology, 2005, 69, 28-45.

[7] Gregory, K.J. The human role in changing river channels. Geomorphology, 2006, 79, 172-191.

[8] Wang, G., Shen, Y., Zhang, J., Wang, S., Mao, S. The effects of human activities on oasis climate and hydrologic environment in the Aksu River Basin, Xinjiang, China. Environ Earth Sci, 2010, 59, 1759-1769.

[9] Ran, L., Wang, S., Lu, X.X. Hydraulic geometry change of a large river: a case study of the upper Yellow River. Environ Earth Sci, 2012, 66, 1246-1257.

[10] VandenBerghe, J., de Moor, J.J.W., Spannjaard, G. Natural change and human impact in a present-day fluvial catchment: the Geul River, Southern Netherlands. Geomorphology, 2012, 159-160, 1-14.

[11] Magliulo, P., Valente, A., Cartojan, E. Recent geomorphological changes of the middle and lower Calore River (Campania, Southern Italy). Environ Earth Sci, 2013,70, 2785-2805.

[12] Wang, B., Xu, Y.J. Dynamics of 30 large channel bars in the Lower Mississippi River in response to river engineering from 1985 to 2015. Geomorphology, 2018, 300, 31-44.

[13] Brandt, S.A., Classification of geomorphological effects downstream of dams. Catena, 2000, 40, 375-401.

[14] Grant, G.E., Schmidt, J.C., Lewis, S.L. A geological framework for interpreting downstream effects of dams on rivers. In O'Connor, J.E. and Grant, G.E., editors. A Peculiar River. American Geophysical Union, Water Science and Applications, 2003, 7, 203-219.

[15] Li, X., Damen, M.C. Coastline change detection with satellite remote sensing for environmental management of the Pearl River Estuary, China. Journal of Marine Systems, 2010, 82, 54-61.

[16] Liro, M. Conceptual model for assessing the channel changes upstream from dam reservoir. Quaestiones Geographicae, 2014 33(1), 61-74.

[17] Ashouri, M., Piry, Z., Moghaddam, R.M.H. A comparison of the influence of the Sattarkhan reservoir dam on the upstream and downstream of the Ahar Chai River, NW Iran. Environ Earth Sci, 2015, 73, 4099-4108.

[18] Carroll, R.W.H., Warwick, J.J., James, A.I., Miller, J.R. Modeling erosion and overbank deposition during extreme flood conditions on the Carson River, Nevada. J Hydrol, 2004, 297, 1-21.

[19] Cluett, L. The role of flooding in morphological changes in the regulated Lower Ord River in tropical northwestern Australia. River Res Appl, 2005, 21, 215-227.
[20] Magliulo, P., Valente, A., Colloca, M., Lo Curzio, S. Geomorphological changes of the Calore River near Benevento (Southern Italy) in modern times: flood hazard implications. Epitome, 2005 , 1, 173-174.

[21] Miller, J.R., Craig Kochel, R. Assessment of channel dynamics, in-stream structures and post-project channel adjustments in North Carolina and its implications to effective stream restoration. Environ Earth Sci, 2010, 59, 1681-1692.

[22] Liu, H.; Lan, H., Liu, Y., Zhou, Y. Characteristics of spatial distribution of debris flow and the effect of their sediment yield in main downstream of Jinsha River, China. Environ Earth Sci, 2011, 64, 1653-1666.

[23] Kiss, T., Blanka, V. River channel response to climate- and humaninduced hydrological changes: case study on the meandering Hernád River, Hungary. Geomorphology, 2012, 175-176, 115-125.

[24] Zhou, H., Zhang, X., Xu, H., Ling, H., Yu, P. Influences of climate change and human activities on Tarim River runoffs in China over the past half Century. Environ Earth Sci, 2012, 67, 231-241.

[25] Liu, Y., Huang, H., Qiu, Z., Fan, J. Detecting coastline change from satellite images based on beach slope estimation in a tidal flat. International J of Applied Earth Observation and Geoinformation, 2013, 23, 165-176.

[26] Chatters, J.C., Hoover, K.A. Response of the Columbia River fluvial system to Holocene climatic change. Quater Res, 1992, 37, 42-59.

[27] Lewis, S.G., Maddy, D., Scaife, R.G. The fluvial system response to abrupt climate change during the last cold stage: the Upper Pleistocene River Thames fluvial succession at Ashton Keynes, UK. Global Planet Change, 2001, 28 (1), 341-359.

[28] Marchetti, M. Environmental changes in the central Po Plain (northern Italy) due to fluvial modifications and anthropogenic activities. Geomorphology, 2002, 44, 361-373.

[29] Thomas, M.F., Nott, J., Murray, A.S., Price, D.M. Fluvial response to late Quaternary climate change in NE Queensland, Australia. Palaeogeogr Palaeocl, 2007, 251, 119-136.

[30] Dogan, U. Fluvial response to climate change during and after the last glacial maximum in Central Anatolia, Turkey. Quater Int, 2010, 222, 221-229.

[31] Liu, W., Cai, T., Fu, G., Zhang, A., Liu, C., Yu, H. The streamflow trend in Tangwang River basin in northeast China and its difference response to climate and land use change in sub-basins. Environ Earth Sci, 2012, 69(1), 51-62.

[32] Miao, C., Yang, L., Liu, B., Gao, Y., Li, S. Streamflow changes and its influencing factors in the mainstream of the Songhua River basin, Northeast China over the past 50 years. Environ Earth Sci, 2011, 63, 489-499.

[33] Liebault, F., Clement, P., Piegay, H., Rogers, C.F., Kondolf, G.M., Landon, N. Contemporary channel changes in the Eygues basin, southern French Prealps: the relationship of subbasin variability to watershed characteristics. Geomorphology, 2002, 45, 53-66.

[34] Hughes, M.L., McDowell, P.F., Marcus, W.A. Accuracy assessment of georectified aerial photographs: implications for measuring lateral channel movement in a GIS. Geomorphology, 2006, 74, 1-16.

[35] Nicoll, T.J., Hichin, E.J. Planform geometry and channel migration of confined meandering rivers on the Canadian praires. Geomorphology, 2010, 116, 37-47.

[36] Khan, N.I., Islam, A. Quantification of erosion patterns in the Brahmaputra-Jamuna River using geographical information system and remote sensing techniques. Hydrological Processes, 2003, 17, 959-966. 
[37] Nasreen, I.K,.Aminul, I. Quantification of erosion patterns in the Brahmaputra- Jamuna River using geographical information system and remote sensing techniques. Hydrol. process, 2003, 17, 959-966.

[38] Kummu, M., Lub, X.X., Rasphonec, A., Sarkkulad, J., Koponen, J. Riverbank Changes along the Mekong River: Remote Sensing Detection in the Vientiane-Nong Khai Area. Quater Inter, 2008, 186 (1), 100-112.

[39] Nutalaya, P. Coastal erosion in the Gulf of Thailand. GeoJournal, 1996, 38(3), 283-300.

[40] Uehara, K., Sojisuporn, P., Saito, Y., Jarupongsakul, T. Erosion and accretion processes in a muddy dissipative coast, the Chao Phraya River delta, Thailand. Earth Surface Processes and Landforms, 2011, 35(14), 1701-1711.

[41] Chuanpongpanich, S., Tanaka, K., Kojiro, T., Arlai, P. Integrated models in the lower part of Chao-Praya river basin for an early flood warning system. Annuals of Disas. Prev. Res. Inst. Kyoto Univ., 2012, 55 B.

[42] Komori, D., Nakamura, S., Kiguchi, M., Nishijima, A., Yamazaki, D., Suzuki, S., Kawasaki, A., Oki, K., Oki, T. Characteristics of the 2011 Chao Phraya River flood in Central Thailand. Hydrological Research Letters, 2012, 6, 41-46.

[43] Ogata, T., Valeriano, O.C.S., Yoshimura, C., Liengcharernsit, W., Hirabayashi, Y. Past and future hydrological simulations of Chao Phraya river basin. Journal of Japan Society of Civil Engineers, 2012, 68(4), 97-102.

[44] Gale, E.L., Saunders, M.A. The 2011 Thailand flood: climate causes and return periods. Weather, 2013, 68(9), 233-237.

[45] Cooper, R.T. Open data flood mapping of Chao Phraya River basin and Bangkok metropolitan region. British J of Envi and Climate Change, 2014, 4(2), 186.

[46] Soo, C.L., Avijit, G., Aik, S.C., Wu, C.A. The flood of 2011 in the lower Chao Phraya valley, Thailand: Study of a long-duration flood through satellite images. Geomorphology, 2016, 262, 112122.

[47] Chuenchooklin, S., River Analysis System Model for Proposed Weirs at Downstream of Large Dam, Thailand. World Academy of Science, Engineering and Technology International Journal of Environmental, Ecological, Geological and Marine Engineering, 2014, 8(9), 600-605

[48] Wang, G., Shen, Y., Zhang, J., Wang, S., and Mao, S., The effects of human activities on oasis climate and hydrologic environment in the Aksu River Basin, Xinjiang, China. Environ Earth Sci, 2010, 59, 1759-1769

[49] Ran, L., Wang, S., and Lu, X. X., Hydraulic geometry change of a large river: a case study of the upper Yellow River. Environ Earth Sci, 2012, 66, 1246-1257

[50] VandenBerghe, J., de Moor, J. J. W., and Spannjaard, G., Natural change and human impact in a present-day fluvial catchment. the Geul River, Southern Netherlands: Geomorphology, 2012, 159-160, 1-14

Wang, B., and Xu, Y. J., Dynamics of 30 large channel bars in the Lower Mississippi River in response to river engineering from 1985 to 2015. Geomorphology, 2018, 300, 31-44

[51] Miller, J. R., and Craig Kochel, R., Assessment of channel dynamics, in-stream structures and post-project channel adjustments in North Carolina and its implications to effective stream restoration. Environ Earth Sci, 2010, 59, 1681-1692

[52] Liu, H., Lan, H., Liu, Y., and Zhou, Y., Characteristics of spatial distribution of debris flow and the effect of their sediment yield in main downstream of Jinsha River, China. Environ Earth Sci, 2011, 64, 1653-1666

[53] Thai Meteorological Department (TMD) Download Data: The Climate of Thailand, 2015 https://www.tmd.go.th/en/archive/ thailand_climate.pdf

[54] Lower Northern Region Irrigation Hydrology Center, the Royal Irrigation Department: Monitoring Report, 2018 https://www. hydro-2.com

[55] Sinsakul, S., Late Quaternary geology of the Lower Central Plain, Thailand. Journal of Asian Earth Sciences, 2000, 18(4), 415-426, doi.org/10.1016/S1367-9120(99)00075-9

[56] Dheeradilok, P., and Kaewyana, W., On the Quaternary deposits of Thailand. Geological Society of Malaysia Bulletin, 1986, 19, 515-532.

[57] Choowong, M., Quaternary. In: Ridd, M. F., Barber, A. J. \& Crow, M. J. (eds) The Geology of Thailand. Geological Society, London, 2011, 273-334.

[58] Charusiri, P., Clark, A.H., Farrar, E., Archibald, D., and, Charusiri, B., Granite belts in Thailand: evidence from the ${ }^{40} \mathrm{Ar} /{ }^{39} \mathrm{Ar}$ geochronological and geological syntheses. Journal of Southeast Asian Earth Sciences, 1993, 8(14), 127-136.

[59] Nutalaya, P., Rau, J.L., Structural framework of the Chao Phraya Basin, Thailand. Proc. of the Symposium of Cenozoic Basins, Chiang Mai University, Thailand, 1984, 106-129

[60] Ramnarong, V., Buapeng, S., Groundwater resources of Bangkok and its vicinity impact and management. Proc. on Geological Resources of Thailand: Potential for Future Development, Bangkok, Thailand, 1992, 172-184.

[61] Coleman, M., Roberts, H.H., Deltaic coastal wetlands. Geologic in Mijnbouw, Kluwer, Dordrecht, 1989, 1-24.

[62] Srikulwongse, S., Jarusiriswadi, R., Petrolium potential of Ayutthaya province. Department of Mineral Resources Special Issue on Kathin Procession, DMR, Bangkok, 1991, 31-36 (in Thai)

[63] Visutimeteegorn, S., Likitdecharote, K., Vongvisessomjai, S., Effects on the upstream flood inundation caused from the operation of Chao Phraya Dam. Songklanakarin J. Sci. Technol., 2007, 29(6), 1662-1674.

[64] Leopold, L.B. Base Level Rise: Gradient of Deposition. Israel Journal of Earth Sciences, 1992, 41, 57-64.

[65] Shields, F.D.J., Simon, A., Steffen, L.J. Reservoir effects on downstream river channel migration. Envi Conserv, 2000, 27(1), 55-66.

[66] Yang, S.L., Belkin, I.M., Belkina, A.I., Zhao, Q.Y., Zhu, J., Ding, X.D. Delta response to decline in sediment supply from the Yangtze River: Evidence of the recent four decades and expectations for the next half-century. Estuarine Coastal Shelf Sci., 2003a, 57, 589-599.

[67] Magilligan, F.J., Nislow, K.H. Changes in hydraulic regime by dams. Geomorphology, 2005, 71, 61-78.

[68] Yang, S.L., Zhang, J., Zhu, J., Smith, J.P., Dai, S.B., Gao, A., Li, P. Impact of dams on Yangtze River sediment supply to the sea and delta intertidal wetland response. J. Geophys. Res., 2005, 110, 1-12.

[69] Baker, D.W., Bledsoe, B.P., Albano, C.M., Poff, N.L. Downstream effects of diversion dams on sediment and hydraulic conditions of Rocky mountain streams. River Research and Applications, 2012, 27, 388-401.

[70] Gupta, H., Kao, S.J., Dai, M. The role of mega dams in reducing sediment fluxes: A case study of large Asian rivers. J of Hydrology, 2012, 464, 447-458. 
[71] Renshaw, C.E., Abengoza, K., Magilligan, F.J., Dade, W.B., Landis, J.D. Impact of flow regulation on near-channel floodplain sedimentation. Geomorphology, 2014, 205, 120-127.

[72] Graf, W.L. Downstream hydrologic and geomorphic effects of large dams on American rivers. Geomorphology, 2006, 79 (3-4), 336-360.

[73] Kummu, M., Varis, O. Sediment related impacts due to upstream reservoir trapping, the Lower Mekong River. Geomorphology, 2007, 85(34), 275-293.

[74] Dai, S., Yang, S., Cai, A. Impacts of dams on the sediment flux of the Pearl River, southern China. Catena, 2008, 76(1), 36-43.

[75] Tangtham, N., Boonyawat, S. Effects of Land Cover Change and Large Reservoir Operation on Water Balance of the Chao Phraya River Basin. Kasetsart J.(Natural Science), 1998, 32, 511-519.

[76] Tebakari, T., Yoshitani, J., Suvanpimol, P. Impact of large-scale reservoir operation on flow regime in the Chao Phraya River basin, Thailand. Hydrological Processes, 2012, 26(16), 2411-2420.

[77] Lane, E.W. The Importance of Fluvial Morphology in Hydraulic Engineering. American Society of Civil Engi $\neg$ neer, Proceedings, 1955, 81(745), 1-17.

[78] Windom, H.L., Silpipat, S., Chanpongsang, A., Smith, R.G., Hungspreugs, M. Trace metal composition of and accumulation rates of sediments in the upper Gulf of Thailand. Estuarine Coastal and Shelf Science, 1984, 19(2), 133-142.

[79] Vongvisessomjai, S., Polsi, R., Manotham, C., Srisaengthong, D., Charulukkana, S. Coastal erosion in the Gulf of Thailand SeaLevel Rise and Coastal Subsidence. Springer: 1996, 131-150.

[80] JICA. The feasibility study on mangrove revival and extension project in the Kingdom of Thailand. Draft Final Report (S. C. a. P. C. Japan International Co-operation Agency (JICA)). Ministry of Agriculture. 2000.

[81] Winterwerp, J.C., Borst, W.G., De Vries, M.B. Pilot study on the erosion and rehabilitation of a mangrove mud coast. J of Coastal Res, 2005, 21(2), 223-230.

[82] Vongvisessomjai, S. Physical environment in the Gulf of Thailand with emphasis on three important ports: The Environment in Asia Pacific Harbours. Springer: 2006, 229-247.

[83] Saito, Y., Chaimanee, N., Jarupongsakul, T., Syvitski, J.P. Shrinking megadeltas in Asia: Sea-level rise and sediment reduction impacts from case study of the Chao Phraya Delta. Inprint Newsletter of the IGBP/IHDP Land Ocean Interaction in the Coastal Zone, 2007, 2, 3-9.
[84] Naohiro, M., Putth, S., Keiyo, M. Mangrove rehabilitation on highly eroded coastal shorelines at Samut Sakhon, Thailand. Inter J of Ecology, 2012.

[85] Sojisuporn, P., Sangmanee, C., Wattayakorn, G. Recent estimate of sea-level rise in the Gulf of Thailand. Maejo Inter J of Sci and Tech, 2013, 7, 106-113.

[86] Williams, S.J. Sea-level rise implications for coastal regions. J of Coastal Res, 2013, 63 (sp1), 184-196.

[87] Syvitski, J.P., Kettner, A.J., Overeem, I., Hutton, E.W., Hannon, M.T., Brakenridge, G.R., Giosan, L. Sinking deltas due to human activities. Nature Geoscience, 2009, 2(10), 681-686.

[88] Bidorn, B. Causes of Shoreline Recession in the Chao Phraya Delta. 2016. Retrieved from http://purl.flvc.org/fsu/fd/FSU_ 2016SU_Bidorn_fsu_0071E_13407.

[89] Walling, D. Human impact on land-ocean sediment transfer by the world's rivers. Geomorphology, 2006, 79, 192-216.

[90] Syvitski, J.P.M., Saito, Y. Morphodynamics of Deltas under the Influence of Humans. Global and Planetary Change, 2007, 57, 261-282.

[91] Syvitski, J.P.M., Harvey, N., Wolanski, E., Burnett, W.C., Perillo, G.M.E, Gornitz, V. Dynamics of the coastal zone. In Coastal Change and the Anthropocene: The Land-Ocean Interactions in the Coastal Zone Project of the International GeosphereBiosphere Programme, Global Change - The IGBP Series. Springer. 2005, pp. 39-94.

[92] Yang, S.L., Belkin, I.M., Belkina, A.I., Zhao, Q.Y., Zhu, J., Ding, X.D. Delta response to decline in sediment supply from the Yangtze River: Evidence of the recent four decades and expectations for the next half-century. Estuarine Coastal Shelf Sci, 2003b, 57, 589-599.

[93] Rao, K.N., Subraelu, P., Naga Kumar, K.C.V., Demudu, G., Hema Malini, B., Rajawat, A.S., Ajai, Impacts of sediment retention by dams on delta shoreline recession: Evidences from the $\mathrm{Kr}$ ishna and Godavari deltas, India. Earth Surface Processes and Landforms, 2010, 35, 817-827.

[94] Dade, W.B., Renshaw, C.E., Magilligan, F.J. Sediment transport constraints on river response to regulation. Geomorphology, 2011, 126, 245-251. 